\title{
Life Cycle Environmental Impacts of Electricity from Biogas Produced by Anaerobic Digestion
}

\author{
Alessandra Fusi ${ }^{1}$, Jacopo Bacenetti ${ }^{2}$, Marco Fiala ${ }^{2}$ and Adisa Azapagic ${ }^{1 *}$ \\ ${ }^{1}$ Sustainable Industrial Systems, School of Chemical Engineering and Analytical Science, The University of Manchester, \\ Manchester, UK, ${ }^{2}$ Dipartimento di Scienze Agrarie e Ambientali - Produzione, Territorio, Agroenergia, Università degli Studi di \\ Milano, Milan, Italy
}

\section{OPEN ACCESS}

Edited by:

Gavin Collins,

National University of Ireland Galway,

Ireland

Reviewed by:

Chu-Ching Lin,

National Central University, Taiwan

Alex Oriel Godoy,

Universidad del Desarrollo, Chile

${ }^{*}$ Correspondence:

Adisa Azapagic

adisa.azapagic@manchester.ac.uk

Specialty section:

This article was submitted to Microbiotechnology, Ecotoxicology and Bioremediation,

a section of the journal

Frontiers in Bioengineering and

Biotechnology

Received: 14 November 2015 Accepted: 23 February 2016

Published: 11 March 2016

Citation:

Fusi A, Bacenetti J, Fiala $M$ and Azapagic A (2016) Life Cycle Environmental Impacts of Electricity from Biogas Produced by Anaerobic

Digestion.

Front. Bioeng. Biotechnol. 4:26. doi: 10.3389/fbioe.2016.00026
The aim of this study was to evaluate life cycle environmental impacts associated with the generation of electricity from biogas produced by the anaerobic digestion (AD) of agricultural products and waste. Five real plants in Italy were considered, using maize silage, slurry, and tomato waste as feedstocks and cogenerating electricity and heat; the latter is not utilized. The results suggest that maize silage and the operation of anaerobic digesters, including open storage of digestate, are the main contributors to the impacts of biogas electricity. The system that uses animal slurry is the best option, except for the marine and terrestrial ecotoxicity. The results also suggest that it is environmentally better to have smaller plants using slurry and waste rather than bigger installations, which require maize silage to operate efficiently. Electricity from biogas is environmentally more sustainable than grid electricity for seven out of 11 impacts considered. However, in comparison with natural gas, biogas electricity is worse for seven out of 11 impacts. It also has mostly higher impacts than other renewables, with a few exceptions, notably solar photovoltaics. Thus, for the AD systems and mesophilic operating conditions considered in this study, biogas electricity can help reduce greenhouse gas (GHG) emissions relative to a fossil-intensive electricity mix; however, some other impacts increase. If mitigation of climate change is the main aim, other renewables have a greater potential to reduce GHG emissions. If, in addition to this, other impacts are considered, then hydro, wind, and geothermal power are better alternatives to biogas electricity. However, utilization of heat would improve significantly its environmental sustainability, particularly global warming potential, summer smog, and the depletion of abiotic resources and the ozone layer. Further improvements can be achieved by banning open digestate storage to prevent methane emissions and regulating digestate spreading onto land to minimize emissions of ammonia and related environmental impacts.

Keywords: agricultural waste, anaerobic digestion, biogas, electricity, life cycle assessment, renewable energy

\section{INTRODUCTION}

The need to mitigate climate change and improve security of energy supply is driving a growing interest in renewable energy sources, with many world regions and countries setting ambitious targets. For example, the EU directive on the promotion of the use of energy from renewable sources (EC, 2009) sets the target of achieving a $20 \%$ share of energy from renewable resources by 2020 , including biogas produced by anaerobic digestion (AD) of agricultural feedstocks. 
Production of biogas is expanding rapidly in Europe. According to EurObserv'ER (2014), about 13.4 million ton oil equivalent (Mtoe) of biogas primary energy was produced in the EU during 2013, a 10\% increase on the 2012 levels. Germany is the largest producer of biogas, not only in Europe but also in the world. In 2013, it had 7874 AD plants with a total installed electrical capacity of $3384 \mathrm{MW}$, which generated $27 \mathrm{TWh}$ /year (EurObserv'ER, 2014; Fuchsz and Kohlheb, 2015). By comparison, the second largest world producer - China - generates just over one-quarter of that (7.6 TWh/year in 2009) (Chen et al., 2012). Italy follows closely in third place at 7.4 TWh of electricity per year produced by $1300 \mathrm{AD}$ plants with a total installed capacity of $1000 \mathrm{MW}$ (Brizzo, 2015). The plants are fed largely with maize grown specifically for this purpose, which in Italy occupies $10 \%$ of the total maize cultivation area $(1,172,000 \mathrm{ha})$ (Casati, 2011). However, this is still only half the area in Germany $(2,282,000 \mathrm{ha})$ where it covers one-third of the total maize land (Dressler et al., 2012).

The rapid expansion of biogas production in Europe is largely due to the feed-in-tariffs (FiT) schemes available in 29 countries (Whiting and Azapagic, 2014). For example, electricity generators in Italy using biogas produced in $\mathrm{AD}$ plants smaller than $1 \mathrm{MW}$ are paid $€ 280 / \mathrm{MWh}$ generated. In the UK, the subsidies are significantly lower, ranging from $€ 130$ to $210 / \mathrm{MWh}$, depending on the plant size (Whiting and Azapagic, 2014). This perhaps explains why the deployment of $\mathrm{AD}$ was initially slower than in Italy, with only $180 \mathrm{AD}$ plants installed so far, but with a further 500 projects currently under development (NNFCC, 2015). However, the FiT scheme in Italy has recently been changed, reducing the subsidy for electricity by $15-30 \%$ and introducing payments for utilization of heat and other coproducts (Ministero dello Sviluppo Economico, 2012). In the US, the growth of biogas production has also been slower than elsewhere, with only 244 AD plants currently in operation (Ebner et al., 2015); this is largely due to the absence of adequate subsidies.

Biogas produced by $\mathrm{AD}$ is considered to have a high saving potential with respect to greenhouse gas (GHG) emissions (EC, 2009). However, beyond that, other environmental implications of biogas production are still unclear despite quite a few life cycle assessment (LCA) studies having been carried out. This is due to several reasons. First, most previous studies of biogas have either focused on climate change or considered a limited number of impacts; for a summary, see Table 1. As far as the authors are aware, out of 26 studies found in the literature, only five have considered a full suite of impacts normally included in LCA studies, two of which are based in the UK (Mezzullo et al., 2013; Whiting and Azapagic, 2014), one in Argentina (Morero et al., 2015), one in Italy (Pacetti et al., 2015), and one in China (Xu et al., 2015). It is also apparent from Table 1 that the goal, scope, life cycle impact assessment (LCIA) methodology, feedstocks, and geographical regions covered by the studies vary widely. Most studies are based in Europe with several in China and one each in Argentina, Canada, and the US. All plants have a capacity below $1 \mathrm{MW}$, with the majority being around $500 \mathrm{~kW}$ (where reported); some are electricity only and others combined heat and power (CHP) installations. Most studies have excluded the impacts of constructing and decommissioning the $\mathrm{AD}$ and power plants. Maize is the most commonly considered feedstock, followed by animal slurry. The functional unit is largely based either on a unit of feedstock used to generate biogas or a unit of energy (biogas, heat, or electricity). Most studies have relied on secondary foreground data to estimate the impacts or used only limited primary data. However, the greatest variation among the studies is found in the number of impacts considered and the methodologies used to estimate them. The former range from 1 to 18 and the latter cover almost all known LCIA methods, including EcoIndicator 99 (Goedkoop and Spriensma, 2001), CML 2001 (Guinée et al., 2002), Impact 2002+ (Olivier et al., 2003), and ReCiPe (Goedkoop et al., 2009). These and the other differences, including the credits for coproducts, have led to very different results among the studies, making it difficult to compare them, and draw any generic conclusions on the environmental sustainability of biogas.

This study aims to make further contributions to the discussion on the environmental sustainability of biogas. The paper considers life cycle environmental impacts of electricity generation in five real $\mathrm{AD}$-CHP systems using biogas produced from differing mixes of four types of feedstock. The plants are situated in Italy. The novel aspects of the work compared to previous studies include:

- estimation of impacts associated with electricity generated from biogas using different feedstocks, including dedicated maize crops, their mixture with animal slurry, and agricultural waste as well as a mixture of slurry and waste;

- use of primary data for both the feedstock production and operation of the AD-CHP systems;

- consideration of the influence of different scales of the $\mathrm{AD}$-CHP systems on the environmental impacts;

- inclusion of construction and decommissioning of $\mathrm{AD}$ and CHP plants;

- estimation of the avoided emissions from using the digestate instead of slurry as fertilizer; and

- comparison of impacts with grid electricity, natural gas, and renewable sources of electricity.

\section{MATERIALS AND METHODS}

The environmental impacts of biogas electricity were estimated using LCA as a tool. The study was carried out in accordance with the ISO 14040/44 methodology for LCA (ISO, 2006a,b). The systems were modeled using Gabi LCA software V6.11 (Thinkstep, 2015). The CML 2001 method (Guinée et al., 2002), April 2013 update, was followed to estimate the following 11 impacts considered in this method: abiotic depletion potential of elements (ADP elements), abiotic depletion potential of fossil fuels (ADP fossil), acidification potential (AP), eutrophication potential (EP), freshwater aquatic ecotoxicity potential (FAETP), global warming potential (GWP), human toxicity potential (HTP), marine aquatic ecotoxicity potential (MAETP), ozone layer depletion potential (ODP), photochemical oxidants creation potential (POCP), also known as summer smog, and terrestrial ecotoxicity potential (TETP). For further details on the estimation of the impacts, see Supplementary Material. 


\begin{tabular}{|c|c|c|c|c|c|c|c|c|c|}
\hline Reference & Country & $\begin{array}{l}\text { No. of } A D \\
\text { plants }\end{array}$ & Plant size & Feedstocks $^{a}$ & Functional unit & $\begin{array}{l}\text { Foreground } \mathrm{LCl} \\
\text { data }^{\mathrm{b}}\end{array}$ & Capital goods & Impacts (LCIA method) ${ }^{c}$ & Best options ${ }^{c}$ \\
\hline $\begin{array}{l}\text { Jury et al. } \\
\text { (2010) }\end{array}$ & Luxemburg & Not reported & Not reported & $\begin{array}{l}\text { - } 4 \text { winter cereals } \\
\text { - } 4 \text { summer cereals }\end{array}$ & $\begin{array}{l}1 \mathrm{MJ} \text { supplied to } \\
\text { the natural gas grid }\end{array}$ & Secondary & Excluded & GWP and CED (impact 2002+) & Not reported \\
\hline $\begin{array}{l}\text { De Vries et al. } \\
\text { (2010) }\end{array}$ & Western Europe & Not reported & Not reported & $\begin{array}{l}\text { - Cattle slurry } \\
\text { - Maize silage } \\
\text { - Codigestion of } \\
\text { above }\end{array}$ & $\begin{array}{l}1 \text { ton of feedstock } \\
\text { (wet) }\end{array}$ & Secondary & Excluded & $\begin{array}{l}\text { GWP, AP, EP, CED, and LU (not } \\
\text { specified) }\end{array}$ & $\begin{array}{l}\text { Codigestion for GWP, EP, AP, } \\
\text { and CED; slurry for LU }\end{array}$ \\
\hline $\begin{array}{l}\text { Blengini et al. } \\
\text { (2011) }\end{array}$ & Italy & Not reported & Not reported & $\begin{array}{l}\text { - Maize } \\
\text { - Sorghum } \\
\text { - Triticale } \\
\text { - Miscanthus } \\
\text { - Slurry }\end{array}$ & $\begin{array}{l}1 \mathrm{MJ} \text { of net energy } \\
\text { (heat or electricity) } \\
\text { delivered }\end{array}$ & Secondary & Included & 6 (CML 2001) & $\begin{array}{l}\text { Miscanthus for GWP, EP, } \\
\text { and AP; maize silage for } \\
\text { photochemical smog }\end{array}$ \\
\hline $\begin{array}{l}\text { Dressler et al. } \\
(2012)\end{array}$ & Germany & 1 & $510 \mathrm{~kW}$ & - Maize silage & $1 \mathrm{kWh}$ of electricity & Secondary & Excluded & GWP, AP, EP (CML 2001) & Not reported \\
\hline $\begin{array}{l}\text { Lansche and } \\
\text { Müller (2012) }\end{array}$ & Germany & 1 & $186 \mathrm{~kW}$ & $\begin{array}{l}\text { - Cattle slurry } \\
\text { - Maize silage } \\
\text { - Grass silage } \\
\text { - Codigestion of } \\
\text { above }\end{array}$ & $1 \mathrm{MJ}$ of electricity & Primary & Excluded & GWP, AP, EP (CML 2001) & Cattle slurry \\
\hline $\begin{array}{l}\text { Meyer-Aurich } \\
\text { et al. (2012) }\end{array}$ & Germany & 1 & $500 \mathrm{~kW}$ & $\begin{array}{l}\text { - Cattle slurry } \\
\text { - Maize silage } \\
\text { - Codigestion of } \\
\text { above }\end{array}$ & $1 \mathrm{kWh}$ of electricity & Secondary & Excluded & GWP (IPCC, 2007) & Cattle slurry \\
\hline $\begin{array}{l}\text { De Vries et al. } \\
\text { (2012) }\end{array}$ & The Netherlands & 1 & $500 \mathrm{~kW}$ & $\begin{array}{l}\text { - Pig slurry } \\
\text { - Maize silage } \\
\text { - Glycerine } \\
\text { - Beet tails } \\
\text { - Roadside grass } \\
\text { - Codigestion of } \\
\text { above }\end{array}$ & $\begin{array}{l}1 \text { ton of feedstock } \\
\text { (wet) }\end{array}$ & Secondary & Excluded & 7 (ReCiPe mid-point) & $\begin{array}{l}\text { Pig slurry for GWP, AP, ME, and } \\
\text { LU; codigestion for FFD, FE, } \\
\text { and PMF }\end{array}$ \\
\hline $\begin{array}{l}\text { Bacenetti et al. } \\
\text { (2013) }\end{array}$ & Italy & 3 & $250-999$ kW & $\begin{array}{l}\text { - Maize silage } \\
\text { - Pig slurry } \\
\text { - Codigestion of } \\
\text { above }\end{array}$ & $1 \mathrm{kWh}$ of electricity & Primary & Excluded & GWP and CED (IPCC, 2007) & $\begin{array}{l}\text { Pig slurry for GWP; maize silage } \\
\text { for CED }\end{array}$ \\
\hline $\begin{array}{l}\text { Mezzullo et al. } \\
\text { (2013) }\end{array}$ & UK & 1 & Not reported & - Cattle slurry & $1 \mathrm{~m}^{3}$ of methane & Secondary & Included & 11 (Ecoindicator 99) & Not reported \\
\hline $\begin{array}{l}\text { Zhang et al. } \\
\text { (2013) }\end{array}$ & China & 1 & Not reported & - Household waste & $\begin{array}{l}\text { Household biogas } \\
\text { (digester volume } \\
8 \mathrm{~m}^{3} \text { ) }\end{array}$ & Secondary & Included & $\mathrm{CO}_{2}$ emissions (Not specified) & Not reported \\
\hline $\begin{array}{l}\text { Lijó et al. } \\
\text { (2014a) }\end{array}$ & Italy & 2 & $\begin{array}{l}250 \text { and } \\
500 \mathrm{~kW}\end{array}$ & $\begin{array}{l}\text { - Animal slurry } \\
\text { - Maize silage }\end{array}$ & $\begin{array}{l}1 \text { ton of feedstock } \\
\text { (wet) }\end{array}$ & $\begin{array}{l}\text { Primary only for } \mathrm{AD} \\
\text { and CHP plant }\end{array}$ & Excluded & 8 (ReCiPe mid-point) & Animal slurry \\
\hline $\begin{array}{l}\text { Lijó et al. } \\
\text { (2014b) }\end{array}$ & Italy & 1 & $500 \mathrm{~kW}$ & $\begin{array}{l}\text { - Codigestion of } \\
\text { maize and triticale } \\
\text { silage }\end{array}$ & $\begin{array}{l}100 \mathrm{kWh} \text { of } \\
\text { electricity }\end{array}$ & $\begin{array}{l}\text { Primary only for AD } \\
\text { and CHP plant }\end{array}$ & Excluded & 8 (ReCiPe mid-point) & Maize silage \\
\hline
\end{tabular}




\begin{tabular}{|c|c|c|c|c|c|c|c|c|c|}
\hline Reference & Country & $\begin{array}{l}\text { No. of AD } \\
\text { plants }\end{array}$ & Plant size & Feedstocks $^{a}$ & Functional unit & $\begin{array}{l}\text { Foreground } \mathrm{LCl} \\
\text { data }^{\mathrm{b}}\end{array}$ & Capital goods & Impacts (LCIA method) ${ }^{\mathrm{C}}$ & Best options $^{c}$ \\
\hline $\begin{array}{l}\text { Rodriguez- } \\
\text { Verde et al. } \\
\text { (2014) }\end{array}$ & Spain & 1 & $500 \mathrm{~kW}$ & $\begin{array}{l}\text { - Pig slurry } \\
\text { - Molasses } \\
\text { - Fish } \\
\text { - Biodiesel } \\
\text { - Vinasse residues }\end{array}$ & $\begin{array}{l}110,000 \text { ton/year } \\
\text { of pig slurry }\end{array}$ & $\begin{array}{l}\text { Primary and } \\
\text { secondary }\end{array}$ & Excluded & 6 (CML 2001) & Not reported \\
\hline $\begin{array}{l}\text { Styles et al. } \\
\text { (2014) }\end{array}$ & UK & 4 & $72-185 \mathrm{~kW}$ & $\begin{array}{l}\text { - Food waste } \\
\text { - Cattle slurry } \\
\text { - Maize and grass } \\
\text { - } \text { silage } \\
\text { - Miscanthus } \\
\text { - Codigestion of } \\
\text { above }\end{array}$ & $\begin{array}{l}1 \text { year of farm } \\
\text { operation }\end{array}$ & Secondary & Excluded & $\begin{array}{l}\text { GWP, AP, EP, and RDP (CML } \\
\text { 2010) }\end{array}$ & Slurry and food waste \\
\hline $\begin{array}{l}\text { Whiting and } \\
\text { Azapagic (2014) }\end{array}$ & UK & 1 & 170 kW & $\begin{array}{l}\text { Codigestion of } \\
\text { slurry, cheese whey, } \\
\text { fodder beet, and } \\
\text { maize silage }\end{array}$ & $\begin{array}{l}\text { Cogeneration of } \\
1 \mathrm{MWh} \text { of heat and } \\
\text { electricity }\end{array}$ & $\begin{array}{l}\text { Primary and } \\
\text { secondary }\end{array}$ & Included & 11 (CML 2001) & $\begin{array}{l}\text { Farm waste better than maize } \\
\text { for } 8 \text { out of } 11 \text { impacts }\end{array}$ \\
\hline $\begin{array}{l}\text { Bacenetti and } \\
\text { Fiala (2015) }\end{array}$ & Italy & 5 & $100-999$ kW & $\begin{array}{l}\text { - Cattle slurry } \\
\text { - Pig slurry } \\
\text { - Cereal silage } \\
\text { - Codigestion of } \\
\text { above }\end{array}$ & $1 \mathrm{kWh}$ of electricity & & $\begin{array}{l}\text { Tractors and } \\
\text { equipment } \\
\text { included; AD } \\
\text { and CHP plant } \\
\text { excluded }\end{array}$ & GWP (IPCC, 2007) & Feedstocks \\
\hline $\begin{array}{l}\text { Ebner et al. } \\
\text { (2015) }\end{array}$ & USA & 1 & Not reported & $\begin{array}{l}\text { - Codigestion of } \\
\text { cattle slurry and } \\
\text { food waste }\end{array}$ & $\begin{array}{l}1 \text { ton of feedstock } \\
\text { (wet) }\end{array}$ & Secondary & Excluded & GWP (IPCC, 2007) & Not reported \\
\hline $\begin{array}{l}\text { Fuchsz and } \\
\text { Kohlheb (2015) }\end{array}$ & Germany & 3 & $600 \mathrm{~kW}$ & $\begin{array}{l}\text { - Maize silage } \\
\text { - Cow slurry } \\
\text { - Codigestion of } \\
\text { above }\end{array}$ & $1 \mathrm{kWh}$ of electricity & $\begin{array}{l}\text { Primary only for } \mathrm{AD} \\
\text { plant construction }\end{array}$ & Included & GWP, AP, EP (not specified) & $\begin{array}{l}\text { Maize silage for GWP; slurry for } \\
\text { AP and EP }\end{array}$ \\
\hline $\begin{array}{l}\text { Ingrao et al. } \\
(2015)\end{array}$ & Italy & 1 & $999 \mathrm{~kW}$ & $\begin{array}{l}\text { - Codigestion of } \\
\text { by-products from } \\
\text { wheat processing } \\
\text { and maize silage }\end{array}$ & $1 \mathrm{kWh}$ of electricity & Primary & Excluded & GWP (IPCC, 2007) & Not reported \\
\hline Jin et al. (2015) & China & 1 & Not reported & - Food waste & 1 ton of food waste & Secondary & Excluded & 5 (CML 2001) & Not reported \\
\hline Lijó et al. (2015) & Italy & 1 & 1000 kW & $\begin{array}{l}\text { - Codigestion of pig } \\
\text { slurry and maize } \\
\text { silage }\end{array}$ & $\begin{array}{l}1 \text { ton of feedstock } \\
\text { (wet) }\end{array}$ & $\begin{array}{l}\text { Primary only for AD } \\
\text { and CHP plant }\end{array}$ & Excluded & 8 (ReCiPe mid-point) & Not reported \\
\hline $\begin{array}{l}\text { Morero et al. } \\
\text { (2015) }\end{array}$ & Argentina & 2 & $531-573 \mathrm{~kW}$ & $\begin{array}{l}\text { - Agroindustrial } \\
\text { wastes }\end{array}$ & $\begin{array}{l}1 \mathrm{~m}^{3} \text { of biogas and } \\
1 \mathrm{kWh} \text { of electricity }\end{array}$ & $\begin{array}{l}\text { Primary and } \\
\text { secondary }\end{array}$ & Excluded & 11 (CML 2001) & Not reported \\
\hline $\begin{array}{l}\text { Pacetti et al. } \\
\text { (2015) }\end{array}$ & Italy & 1 & Not reported & $\begin{array}{l}\text { - Maize } \\
\text { - Sorghum } \\
\text { - Wheat silage }\end{array}$ & $\begin{array}{l}1 \text { GJ of energy in } \\
\text { the biogas }\end{array}$ & Secondary & Excluded & 18 (ReCiPe mid-point) & Sorghum \\
\hline
\end{tabular}




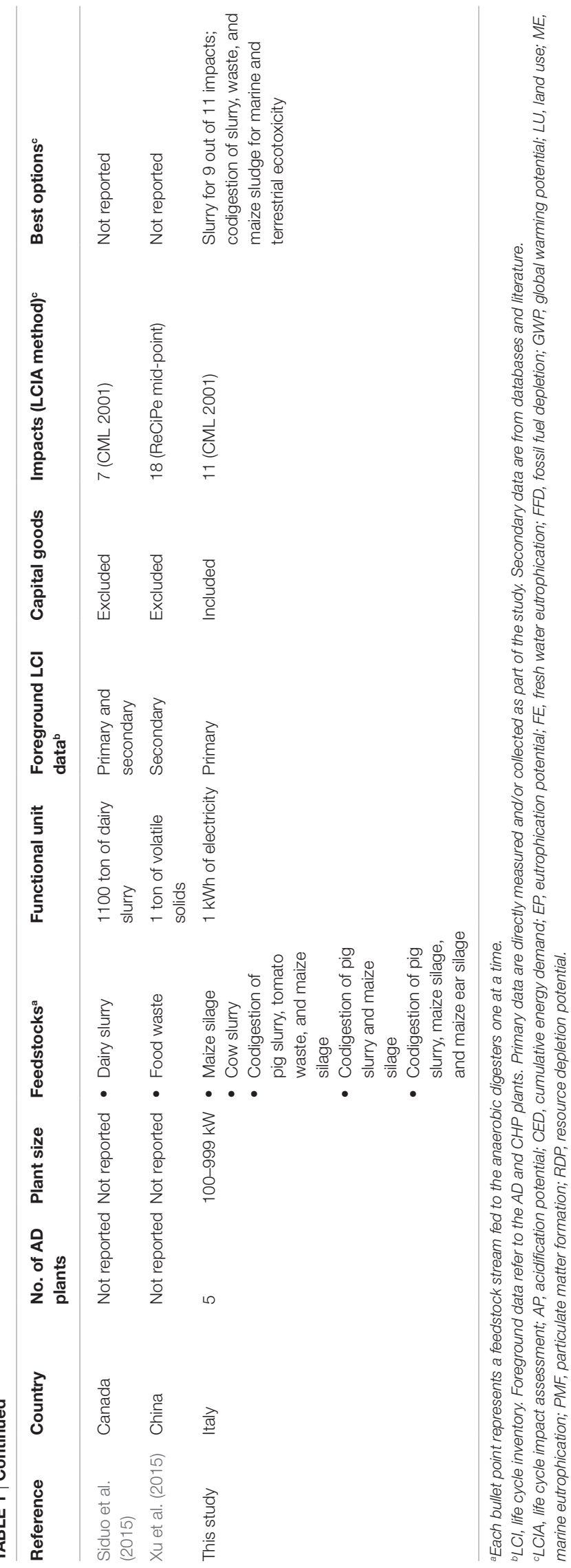

The next sections detail the goal of the study, the assumptions, and data used in the study.

\section{Goal and Scope of the Study}

The main goal of the study was to estimate the environmental impacts of electricity generated by different AD-CHP systems utilizing maize silage and agricultural waste. The results were compared with electricity from the grid, natural gas, and different renewables to help evaluate the environmental sustainability of biogas electricity relative to other available options.

Five real AD-CHP systems were considered using differing combinations of the following feedstocks: maize and maize ear silage; pig and cow slurry; and tomato peel and seeds (Table 2). The volume of the AD digesters ranged from 1650 to $2750 \mathrm{~m}^{3}$ and the installed electrical capacity of the CHP plants from 100 to $999 \mathrm{~kW}$. The plants are located at farms producing the feedstocks in Lombardy in Northern Italy, where the majority of the country's biogas plants are situated (Negri et al., 2014).

As indicated in Figure 1, the scope of the study was from "cradle to grave," including:

- production of maize silage (where used), comprising cultivation, transport from fields to the farm $(1 \mathrm{~km})$, and the ensiling;

- collection of slurry and tomato waste and delivery to the AD plants;

- construction and decommissioning of AD and CHP plants;

- production of biogas in the AD plants and its treatment (filtration, dehumidification, and desulfurization);

- cogeneration of electricity and heat in the CHP plants; the heat, except that used for heating the digesters, is considered as waste as it is not used;

- storage and subsequent use of digestate as fertilizer; note that all plants but no. 2 use open storage of digestate.

Electricity distribution and consumption were excluded from the system boundary.

The functional unit was defined as "generation of $1 \mathrm{MWh}$ of electricity to be fed into the grid." Although heat is cogenerated with electricity, all the impacts were allocated to the latter as the excess heat not utilized in the system is discharged as waste.

\section{Inventory Data \\ Feedstock Production}

The inventory data for the production of maize silage are detailed in Tables S1 and S2 in Supplementary Material. As indicated in the tables, data for field operations were collected directly from the farms. The background data were sourced from Ecoinvent (Nemecek and Kägi, 2007) and modified to match the characteristics of the machinery used for maize cultivation in Lombardy, based on information in Bodria et al. (2006). No environmental impacts were considered for tomato waste and slurry as they are waste.

Ammonia and nitrous oxide emissions as well as nitrate leachates from the application of the digestate and urea as fertilizers were estimated according to Brentrup et al. (2000). Phosphate leachates and run-offs were calculated based on Nemecek and Kägi (2007). To estimate pesticide emissions to the environment, several factors need to be considered, such 
TABLE 2 | Summary of the main characteristics of the AD-CHP plants considered in the study. ${ }^{\text {a }}$

\begin{tabular}{|c|c|c|c|c|c|c|c|c|c|c|}
\hline Plant & Feedstock & $\begin{array}{c}\text { Volume of } \\
\text { AD digesters } \\
\left(\mathrm{m}^{3}\right)\end{array}$ & $\begin{array}{c}\text { Dry matter } \\
\text { content in } \\
\text { digesters (\%) }\end{array}$ & $\begin{array}{l}\text { Organic loading } \\
\text { in digesters } \\
\left(\mathrm{kg} / \text { day } \mathrm{m}^{3}\right)\end{array}$ & $\begin{array}{c}\text { Methane } \\
\text { content in } \\
\text { biogas (\%) }\end{array}$ & $\begin{array}{l}\text { Installed } \\
\text { CHP power } \\
\text { (kW) }\end{array}$ & $\begin{array}{l}\text { Electricity } \\
\text { generation } \\
\text { (MWh/year) }\end{array}$ & $\begin{array}{l}\text { Electricity } \\
\text { consumption } \\
\text { (MWh/year) }\end{array}$ & $\begin{array}{c}\text { Heat } \\
\text { generation } \\
\text { (MWh/year) }\end{array}$ & $\begin{array}{c}\text { Heat } \\
\text { consumption by } \\
\text { AD (MWh/year) }\end{array}$ \\
\hline Plant 1 & $\begin{array}{l}\text { - Pig slurry } \\
\text { - Tomato peel } \\
\text { and seeds } \\
\text { - Maize silage }\end{array}$ & 1650 & 8.7 & 0.92 & 52.8 & 230 & 1945 & 173 & 2549 & 809 \\
\hline Plant 2 & $\begin{array}{l}\text { - Pig slurry } \\
\text { - Maize silage }\end{array}$ & 2250 & 10.6 & 1.07 & 52.6 & 300 & 2429 & 206 & 3184 & 814 \\
\hline Plant 3 & $\begin{array}{l}\text { - } \text { Pig slurry } \\
\text { - Maize silage } \\
\text { - Maize ear } \\
\text { silage }\end{array}$ & 2000 & 9.7 & 0.98 & 52.7 & 300 & 2505 & 276 & 3514 & 799 \\
\hline Plant 4 & - Maize silage & $2 \times 2750$ & 10.7 & 3.40 & 52.1 & 999 & 7972 & 717 & 8771 & 2505 \\
\hline Plant 5 & - Cow slurry & 1850 & 8.5 & 0.58 & 56.0 & 100 & 781 & 86 & 1095 & 547 \\
\hline
\end{tabular}

${ }^{a}$ All data sourced directly from the farm/plant owners.

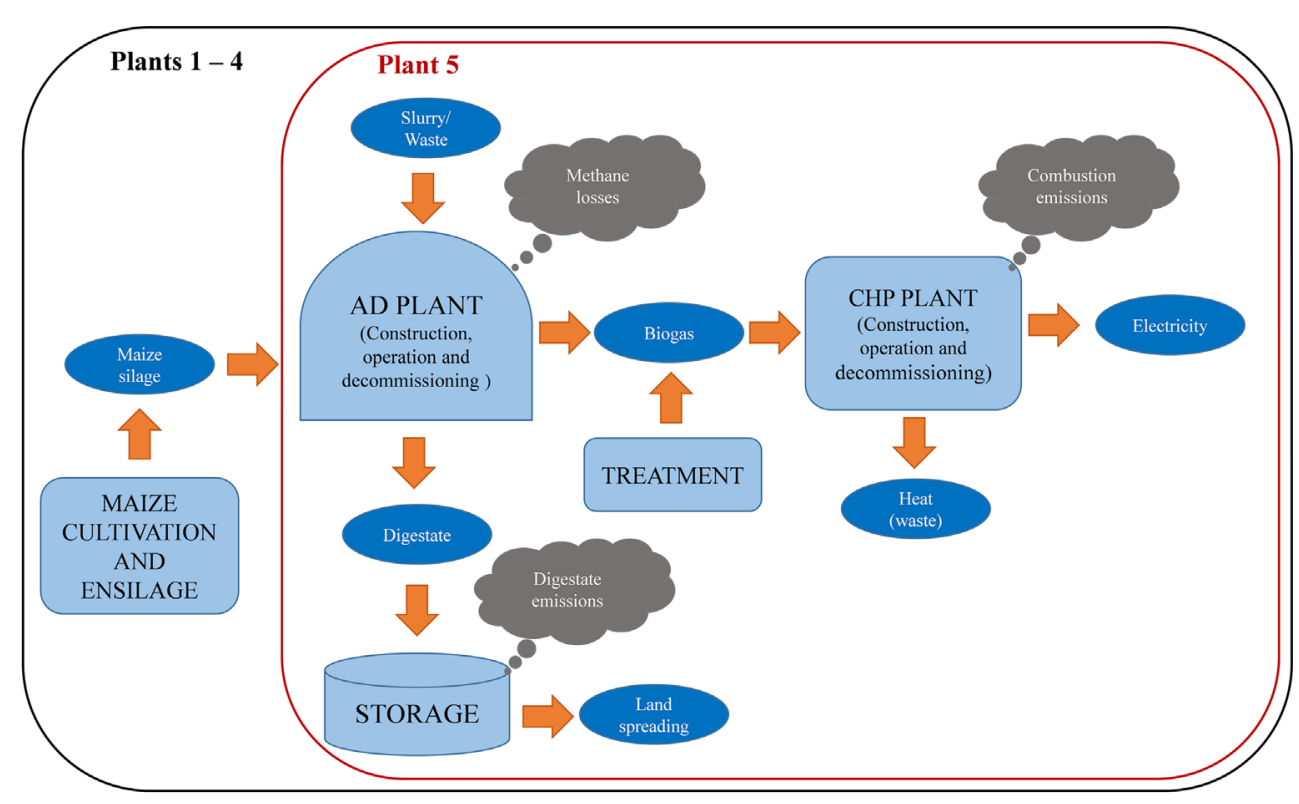

FIGURE 1 System boundaries considered in the study. No environmental impacts are considered for the tomato waste, pig and cow slurry as they are waste. All the impacts are allocated to electricity as heat is not exported from the system.

as the way in which a pesticide is applied, the soil type, and the meteorological conditions during application (EMEP/EEA, 2013). However, considerations of these parameters is often impractical in LCA studies due to a lack of detailed data (Milà i Canals, 2007). Thus, pesticide emissions to air, water, and soil were determined in accordance with Margni et al. (2002) and Audsley (1997), assuming the following partitioning of the active pesticide components: $85 \%$ of the total amount applied remains in the soil, $5 \%$ in the plant, and $10 \%$ is emitted into the atmosphere; furthermore, $10 \%$ of the applied dose is lost as a run-off from the soil into the water. This method is also recommended for use by Curran (2012) and was applied in some other
LCA studies [e.g., Boschiero et al. (2014), Falcone et al. (2015), and Fantin et al. (2015)].

Land use change was not considered as the maize feedstock is grown on land previously used to cultivate cereals.

The transport and packaging of pesticides and fertilizers were not included in the system boundaries because of a lack of data. This is not deemed a limitation as some other studies found that their contribution was insignificant [e.g., Cellura et al. (2012)].

\section{$A D$ and CHP Plants}

In all the $\mathrm{AD}$ plants evaluated in this study, the digestion takes place in continuously stirred reactors under mesophilic conditions at a 
temperature of $40^{\circ} \mathrm{C}\left( \pm 0.2^{\circ} \mathrm{C}\right)$, which is controlled and monitored continuously. Therefore, the digesters are operated at the top end of the temperature scale, which for mesophilic digestion ranges from 30 to $40^{\circ} \mathrm{C}$ (Weiland, 2010). The digesters are made from iron-reinforced concrete and have an expanded polyurethane external insulation. The biomass is fed into the digesters every $90 \mathrm{~min}$ in small amounts and heated using the heat generated by the adjacent CHP. As indicated in Table 2, the dry matter content in the digester varies from 8.5 to $10.6 \%$, and the organic loading rate from 0.58 to $3.4 \mathrm{~kg} /$ day $\mathrm{m}^{3}$. The biogas composition is similar across the plants with the methane content ranging from 52 to $56 \%$ of the biogas volume.

The biogas is stored on top of the digesters in a gasometer dome with a spherical cap. Before being fed into the CHP plant, the biogas is filtered through a sand filter, dehumidified in a chiller, and then desulfurized using sodium hydroxide $(\mathrm{NaOH})$. $\mathrm{NOx}$ emissions are controlled by a catalytic converter. The digestate is pumped from the bottom of the digesters and stored in open tanks in all the plants except for Plant 2, where it is stored in a covered tank.

The biogas is fed into the CHP plant to generate electricity and heat. Electricity is sold to the national grid while the heat is used for heating the digesters and the excess is dissipated by fan-coolers. The electricity consumption for operating the AD plants is sourced from the national grid to ensure continuous operation during the CHP downtimes. The amount of electricity used by the system ranges from 8.5 to $11 \%$ of the total electricity generated (Table 2).

Detailed inventory data for the $\mathrm{AD}$ and $\mathrm{CHP}$ plants can be found in Tables 2 and 3. The operational data (feedstock production, consumption of electricity and heat, electricity generation) were obtained from the owners. Chemical characterization of different types of feedstock and their biogas production potentials were determined by laboratory tests (Fiala, 2012; Negri et al., 2014; Bacenetti et al., 2015) and used to calculate the biogas production by the $\mathrm{AD}$ plants. The emissions from the $\mathrm{CHP}$ plants were calculated based on NERI (2010). The useful lifetime of the AD plants was assumed to be 20 years (Nemecek and Kägi, 2007). For the CHP plants, the lifespan is shorter, between 8 and 10 years because of the high content of hydrogen sulfide (Fiala, 2012). At the end of a plant's useful lifetime, its construction materials were assumed to be landfilled, except for plastic materials, which were incinerated; the influence on the impacts of recycling is explored in a sensitivity analysis later in the paper.

The background data on the construction materials, their transport ( $120 \mathrm{~km}$ by rail and $35 \mathrm{~km}$ in $20-28$ ton trucks) and landfilling were sourced from the Ecoinvent database v2.2 (Ecoinvent, 2010). Since the data for construction materials for the $\mathrm{AD}$ and $\mathrm{CHP}$ plants in Ecoinvent correspond to a different plant size $\left(300 \mathrm{~m}^{3}\right.$ for the $\mathrm{AD}$ and $160 \mathrm{~kW}_{\mathrm{el}}$ for the CHP plants), the environmental impacts from their manufacture were estimated by scaling up or down their capacity to match the sizes of the AD and CHP plants considered in this study. This was carried out following the approach used for cost estimation in scaling up process plants (Coulson et al., 1993) but instead of costs, estimating environmental impacts as follows (Whiting and Azapagic, 2014):

$$
E_{2}=E_{1} \cdot\left(C_{2} / C_{1}\right)^{0.6}
$$

where $E_{2}$ environmental impacts of the larger plant (AD or CHP); $E_{1}$ environmental impacts of the smaller plant (AD or CHP); $C_{2}$ capacity of the larger plant (volume for the $\mathrm{AD}$ plant and installed power for the CHP plant); $C_{1}$ capacity of the smaller plant (volume for the AD plant and installed power for the CHP plant); 0.6 scaling factor.

\section{Digestate Use and Methane Emissions Credits}

In all the plants except no. 4, the digestate is used as fertilizer on the farms, replacing pig or cow slurries applied previously as part of a traditional slurry management method (see Figure 2). Both digestate and the slurry from Plants 1, 3, and 5 are stored in open tanks before application, during which they emit methane. However, the emissions from digestate are lower than from slurry storage (Amon et al., 2006; Wang et al., 2014), and the AD systems were credited for the avoidance of the emissions. Note that in Plant 2, the digestate is stored in covered tanks, with no emissions of methane (IPCC, 2006); thus, the net emissions from this system are negative (Table 3 ).

At Plant 4, a closed maize cycle is practiced, whereby the digestate is used as fertilizer for the maize which is fed into the same plant (Figure 3). The digestate at this plant is stored in open tanks.

\section{Alternative Electricity Sources}

Grid electricity was considered here as the main alternative to electricity from biogas. This is due to the latter being fed into the national grid, displacing an equivalent amount of grid electricity. The Italian electricity mix is shown in Figure S1 in Supplementary Material. Given that the electricity mix is dominated by natural gas (53\%) (IEA, 2011), biogas electricity was also compared to this

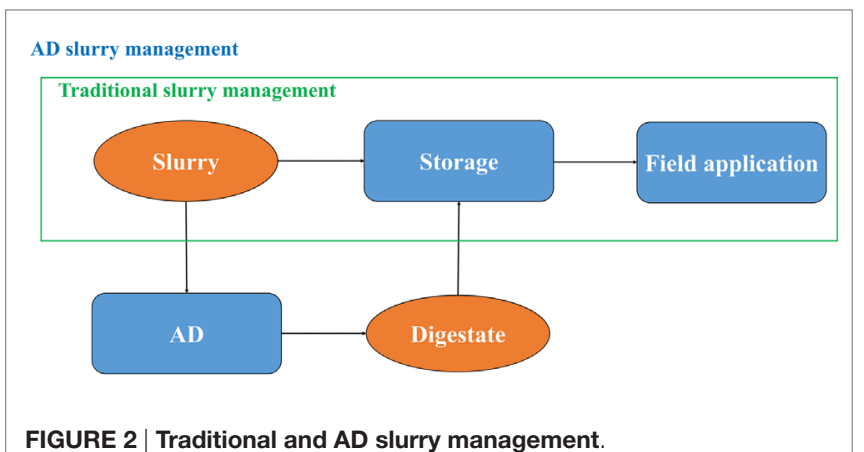

FIGURE 2 | Traditional and AD slurry management

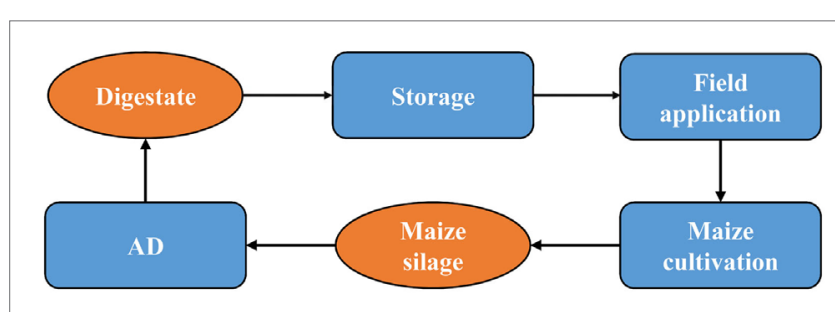

FIGURE 3 | Maize silage cycle. 
TABLE 3 | Inventory data for the AD and CHP plants (expressed per megawatt hour of electricity).

\begin{tabular}{|c|c|c|c|c|c|c|c|}
\hline & Unit & Plant 1 & Plant 2 & Plant 3 & Plant 4 & Plant 5 & Data sources \\
\hline \multicolumn{8}{|l|}{ AD } \\
\hline Pig slurry & ton & 8.4 & 6.0 & 7.3 & - & - & Farm owner \\
\hline Cow slurry & ton & - & - & - & - & 21.0 & $-\|-$ \\
\hline Maize silage & ton & 0.9 & 2.25 & 0.8 & 2.45 & - & $-\|-$ \\
\hline Tomato peel and seeds & ton & 1.5 & - & - & - & - & $-\|-$ \\
\hline Ear maize silage & ton & - & - & 0.66 & - & - & $-\|-$ \\
\hline Water & ton & 0.94 & 0.75 & - & 0.23 & - & $-\|-$ \\
\hline Sodium hydroxide & g & 28.3 & 29.6 & 29.6 & 29.9 & 30.0 & $-\|-$ \\
\hline Electricity from the grid & $\mathrm{MWh}$ & 0.09 & 0.09 & 0.11 & 0.09 & 0.11 & $-\|-$ \\
\hline Heat from CHP & $\mathrm{MWh}$ & 0.42 & 0.34 & 0.32 & 0.38 & 0.70 & $-\|-$ \\
\hline Net biogas production & $\mathrm{Nm}^{3}$ & 280 & 278 & 289 & 252 & 285 & Own calculations based on farm owner's data \\
\hline \multicolumn{8}{|l|}{ CHP } \\
\hline Electricity generated & $\mathrm{MWh}$ & 1 & 1 & 1 & 1 & 1 & $-\|-$ \\
\hline Heat generated & $\mathrm{MWh}$ & 1.3 & 1.3 & 1.4 & 1.1 & 1.4 & Own calculations based on farm owner's data \\
\hline \multicolumn{8}{|l|}{ Emissions associated with AD } \\
\hline Methane emissions from AD plant & $m^{3}$ & 3.8 & 3.8 & 4.0 & 3.4 & 3.9 & Bacenetti et al. (2013) \\
\hline Methane emissions from digestate storage & $\mathrm{kg}$ & 8.9 & 0 & 8.9 & 8.9 & 8.9 & Edelmann et al. (2011) \\
\hline $\begin{array}{l}\text { Credit for avoiding methane emissions from } \\
\text { slurry storage }\end{array}$ & $\mathrm{kg}$ & -6.9 & -6.3 & -6.0 & 0 & -32.0 & Amon et al. (2006) and Wang et al. (2014) \\
\hline Net emissions of methane & $\mathrm{kg}$ & 5.9 & -2.5 & 6.9 & 12.3 & -19.2 & Own calculations \\
\hline Ammonia emissions from digestate storage & $\mathrm{kg}$ & 0.2 & 0.0 & 0.2 & 0.2 & 0.2 & Edelmann et al. (2011) \\
\hline \multicolumn{8}{|l|}{ Emissions from CHP } \\
\hline $\mathrm{NOx}$ & $g$ & 56.1 & 56.1 & 56.1 & 56.1 & 56.1 & NERI (2010) \\
\hline NMVOC $^{a}$ & $g$ & 2.8 & 2.8 & 2.8 & 2.8 & 2.8 & $-\|-$ \\
\hline $\mathrm{CH}_{4}$ & $g$ & 120.6 & 120.6 & 120.6 & 120.6 & 120.6 & $-\|-$ \\
\hline $\mathrm{CO}$ & $g$ & 86.1 & 86.1 & 86.1 & 86.1 & 86.1 & $-\|-$ \\
\hline $\mathrm{N}_{2} \mathrm{O}$ & $\mathrm{mg}$ & 444 & 444 & 444 & 444 & 444 & $-\|-$ \\
\hline As & $\mathrm{mg}$ & 11 & 11 & 11 & 11 & 11 & $-\|-$ \\
\hline $\mathrm{Cd}$ & $\mathrm{mg}$ & 1 & 1 & 1 & 1 & 1 & $-\|-$ \\
\hline Co & $\mathrm{mg}$ & 58 & 58 & 58 & 58 & 58 & $-\|-$ \\
\hline $\mathrm{Cr}$ & $\mathrm{mg}$ & 50 & 50 & 50 & 50 & 50 & $-\|-$ \\
\hline $\mathrm{Cu}$ & $\mathrm{mg}$ & 86 & 86 & 86 & 86 & 86 & $-\|-$ \\
\hline $\mathrm{Hg}$ & $\mathrm{mg}$ & 33 & 33 & 33 & 33 & 33 & $-\|-$ \\
\hline $\mathrm{Mn}$ & $\mathrm{mg}$ & 53 & 53 & 53 & 53 & 53 & $-\|-$ \\
\hline $\mathrm{Ni}$ & $\mathrm{mg}$ & 64 & 64 & 64 & 64 & 64 & $-\|-$ \\
\hline $\mathrm{Pb}$ & $\mathrm{mg}$ & 1 & 1 & 1 & 1 & 1 & $-\|-$ \\
\hline $\mathrm{Sb}$ & $\mathrm{mg}$ & 33 & 33 & 33 & 33 & 33 & $-\|-$ \\
\hline $\mathrm{Se}$ & $\mathrm{mg}$ & 58 & 58 & 58 & 58 & 58 & $-\|-$ \\
\hline $\mathrm{Tl}$ & $\mathrm{mg}$ & 58 & 58 & 58 & 58 & 58 & $-\|-$ \\
\hline V & $\mathrm{mg}$ & 11 & 11 & 11 & 11 & 11 & $-\|-$ \\
\hline $\mathrm{Zn}$ & $\mathrm{mg}$ & 1097 & 1097 & 1097 & 1097 & 1097 & $-\|-$ \\
\hline
\end{tabular}

aNon-methane volatile organic compounds.

option. Furthermore, as biogas is a renewable resource, it was also compared to the other renewables contributing to the Italian mix (see Figure S1 in Supplementary Material). The system boundary for all the alternatives was from "cradle to grave," and all the data were sourced from Ecoinvent (2010). As for the biogas electricity, distribution and consumption of electricity were not considered.

\section{RESULTS}

The results suggest that biogas electricity generated by Plant 5 is environmentally the best option among the five plants considered (Figure 4), largely because it does not use maize silage as a feedstock. The exceptions to this are the MAETP and TETP for which Plant 1 is slightly better because these impacts are not affected by maize silage (as discussed further below). Plant 1 is also the second best option for all other impacts apart from GWP and POCP, for which Plant 2 is better because of the lower methane emissions from digestate.

The differences in the impacts for Plants 2 and 4, which are fed with approximately the same amount of maize silage, are due to the differences in the digestate emissions and the capacities of the $\mathrm{AD}$ and $\mathrm{CHP}$ plants.

Despite the highest biogas production, Plant 3 is the worst option across all the impact categories because of the maize ear silage, which has impacts twice as high as maize silage owing to its lower yield (Table S2 in Supplementary Material). The exceptions to this are GWP and POCP, for which Plant 4 is worst because of the higher net methane emissions (Table 3). 
The following sections discuss in more detail the impacts from the different plants (Figure 4) and the contributions of different life cycle stages (Figures 5A-E).

\section{Abiotic Depletion Potential (ADP Elements and ADP Fossil)}

Abiotic depletion of elements and fossil resources range from 142 to $243 \mathrm{mg} \mathrm{Sb}$ eq./MWh and from 1010 to $1570 \mathrm{MJ} / \mathrm{MWh}$, respectively, with Plant 5 being the best and Plant 3 the worst option for both impacts.

As indicated in Figures 5A-D, the depletion of elements for Plants 1-4 is mainly due to the cultivation of maize and is associated with the materials used for agricultural machinery. For Plant 5 , on the other hand, the major contributors are construction materials for the AD and CHP plants (Figure 5E); the latter is also a hotspot for Plant 1 . This is due to economies of scale: they have smaller CHP plants and thus a higher consumption of resources per megawatt hour electricity generated.

As also shown in Figures 5A-D, the major contributors to fossil depletion for Plants 1-4 are the fuel used in the agricultural machinery for maize cultivation and the electricity for the $\mathrm{AD}$ plants. For Plant 5, the grid electricity used to operate the AD plant accounts for the majority of this impact (Figure 5E).

\section{Acidification and Eutrophication Potentials}

The estimated AP varies from 2.6 to $5.5 \mathrm{~kg} \mathrm{SO}$ eq./MWh and EP from 0.2 to $1.9 \mathrm{~kg} \mathrm{PO}_{4}$ eq./MWh. As for ADP, biogas electricity generated by Plant 5 is the best and by Plant 3 the worst option for these two impacts. For Plants 1-4, maize cultivation is responsible for the large majority of $\mathrm{AP}$ and $\mathrm{EP}$ (Figure 5A-D), whereas for Plant 5 (Figure 5E), it is the ammonia emitted during the digestate storage as well as the emissions of acid gases and nutrients in the life cycle of the grid electricity used for AD.

\section{Global Warming Potential (GWP 100 years)}

The values for GWP range from -395 to $408 \mathrm{~kg} \mathrm{CO}_{2}$ eq./MWh, with electricity from Plant 5 being the best option and from Plant 4 the worst. The vast majority of GWP (64\%) is due to methane emissions from the digestate during its storage. For Plant 2, GWP is mainly from the maize silage (Figure 5B). The negative contributions shown in the figure are due to the methane credits for the avoidance of the traditional slurry management, as described in Section "Digestate Use and Methane Emissions Credits." For Plant 5, the methane credits are higher than the methane emissions from the digestate, leading to a negative impact of $-395 \mathrm{~kg}$ $\mathrm{CO}_{2}$ eq./MWh (Figure 5E). Note that carbon dioxide emissions from biogas combustion in the CHP plant are not considered as they are biogenic in nature.

\section{Human Toxicity Potential}

This impact is lowest for electricity generated by Plants 1 and 5 [79 kg dichlorobenzene (DCB) eq./MWh] and highest for Plant 3 (114 kg DCB eq./MWh). For Plants 1-4, the main contributor is the production of maize silage and the emissions from biogas combustion, in particular chromium and thallium (see Table 3). For Plant 5, HTP is mainly affected by CHP operation, followed by $\mathrm{AD}$ operation and plant construction (Figure $5 \mathrm{E}$ ).

\section{Ecotoxicity Potentials (FAETP, MAETP, and TETP)}

The lowest FAETP is estimated for Plant 1 (198 kg DCB eq./ MWh) and the highest for Plant 3 (413 kg DCB eq./MWh). The

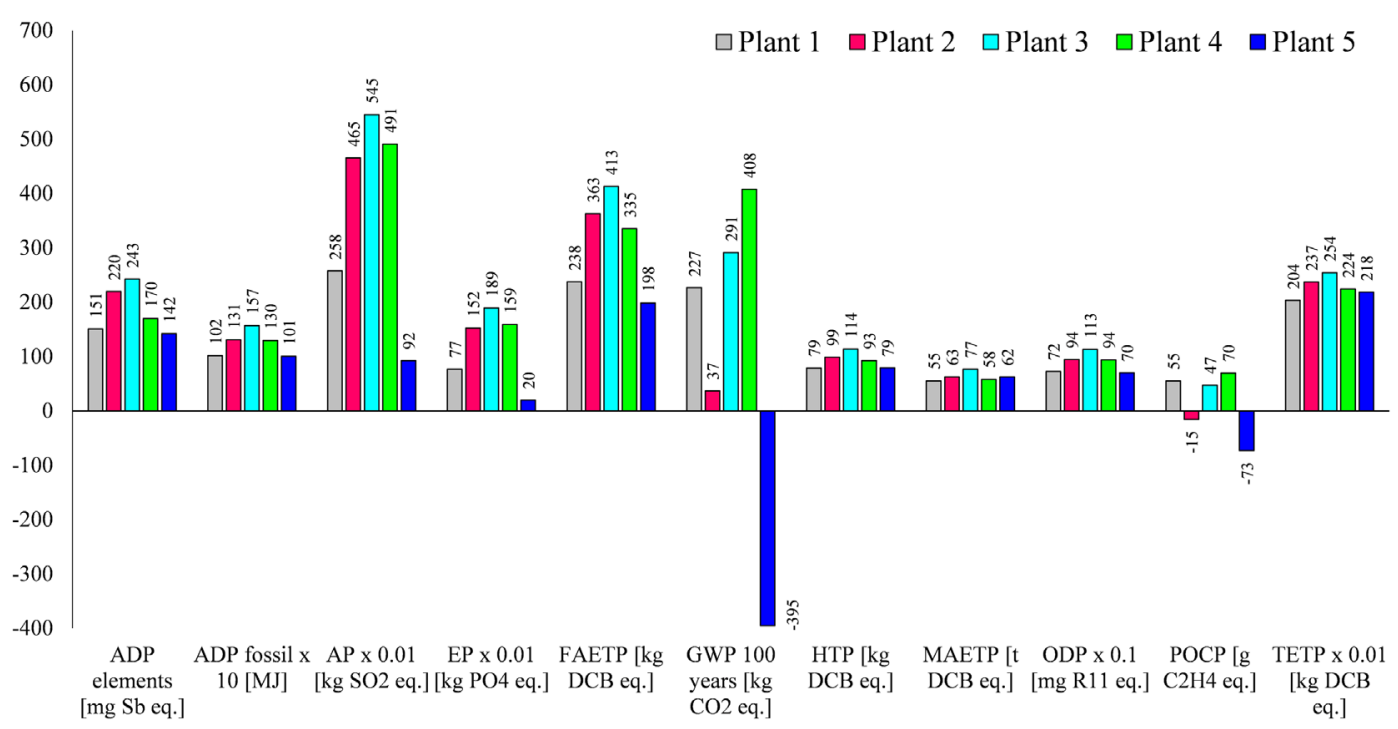

FIGURE 4 | The environmental impacts associated with the generation of biogas electricity. All impacts expressed per megawatt hour of electricity generated. Impacts nomenclature: ADP elements, abiotic depletion potential for elements; ADP fossil: abiotic depletion potential for fossil fuels; AP, acidification potential; EP, eutrophication potential; FAETP, freshwater aquatic ecotoxicity potential; GWP, global warming potential; HTP, human toxicity potential; MAETP, marine aquatic ecotoxicity potential; ODP, ozone depletion potential; POCP, photochemical oxidants creation potential; TETP, terrestrial ecotoxicity potential; DCB, dichlorobenzene. 


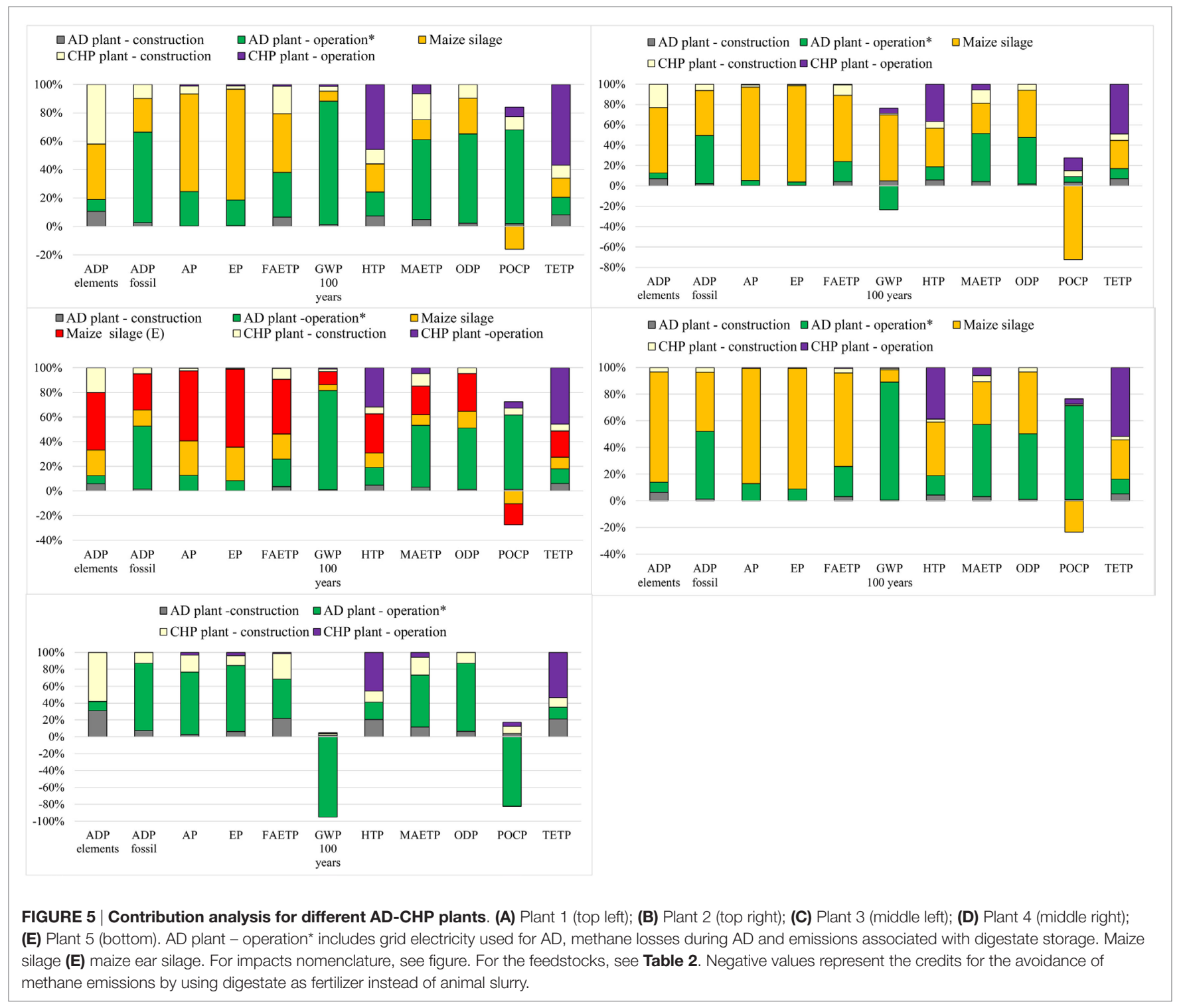

production of maize silage and the plant operation are the main contributors to this impact for Plants 1-4. This is mainly due to the emissions of pesticide used for maize cultivation (Table 3) and metals (nickel, beryllium, cobalt, and vanadium) emitted in the life cycle of the grid electricity. It can be noted that Plant 1 has lower MAETP and TETP, which is due to the efficiency associated with economies of scale as these impacts are mainly influenced by the plant operation (Figures 5A,E).

Unlike HTP, the best option for MAETP is Plant 5 at 55 ton DCB eq./MWh but, as for HTP, Plant 3 has the highest impact (77 ton DCB eq./MWh). The main hotspot is grid electricity used for $\mathrm{AD}$ because of the emissions of beryllium and hydrogen fluoride in the life cycle of electricity generation.

The same trend is found for TETP, with Plant 5 being the best option (2 kg DCB eq./MWh) and Plant 3 the worst $(2.5 \mathrm{~kg} \mathrm{DCB}$ eq./MWh). Maize silage and CHP operation are the main contributors to TETP for Plants 1-4. Like HTP, the latter is mainly due to the emissions of chromium and thallium from biogas combustion. For Plant 5, CHP operation is the main hotspot (biogas combustion), followed by $\mathrm{AD}$ operation and plant construction.

\section{Ozone Layer Depletion Potential}

At $7 \mathrm{mg}$ R11 eq./MWh, Plant 5 has the lowest ODP and, as for most other impacts, Plant 3 the highest (11.3 mg R11 eq./MWh). The main contributors are halons emitted in the life cycle of grid electricity used in $\mathrm{AD}$ (related to natural gas transportation), followed by the emissions from diesel used in the machinery during maize cultivation (Plants 1-4).

\section{Photochemical Oxidants Creation Potential}

The POCP ranges from $-73 \mathrm{~g} \mathrm{C}_{2} \mathrm{H}_{4}$ eq./MWh for Plant 5 to $70 \mathrm{~g}$ $\mathrm{C}_{2} \mathrm{H}_{4}$ eq./MWh for Plant 3. For Plants 1,3 , and 4 , the impact is 
largely due to the emissions of methane from the digestate and the methane losses from the $\mathrm{AD}$ plant. The negative contributions (Figure 5) are due to two reasons: first, according to the CML 2001 method, nitrogen oxides emitted during the cultivation of maize reduce POCP (Plants 1-4); and second, because of the methane credits (Plant 5).

\section{Comparison with Alternative Electricity Sources}

The biogas electricity is compared to electricity from the grid, natural gas, and renewables in Figure 6 and the ranking of different options with respect to each impact is summarized in the heat map in Figure 7.

As can be seen in Figure 6, grid electricity has higher impacts than electricity from biogas for seven out of 11 categories: ADP fossil, FAETP, GWP, HTP, MAETP, ODP, and POCP. This is mainly due to the high contribution of fossil fuels in the Italian electricity mix. An exception to this is Plant 3 which has a higher HTP than the grid because of the toxic emissions in the life cycle of maize ear silage.
Electricity from the grid also has lower AP (by 10-57\%) and EP (32-72\%) than biogas electricity; this is due to maize cultivation which contributes significantly to these two impacts (see Figure 5). The exception to this is Plant 5 which has lower impacts than grid electricity (by $\sim 60 \%$ ) because it does not use maize silage.

Two further impacts are lower for grid electricity: depletion of elements and TETP. This could be explained by the greater economies of scale of the plants on the grid, which require a lower amount of resources and thus have lower toxic emissions on a life cycle basis per unit of electricity generated than the agricultural machinery and the AD-CHP plants.

Unlike grid electricity, electricity from natural gas is environmentally more sustainable than biogas for most categories, except ADP fossil, GWP, ODP, and POCP (Figure 6). In comparison to the renewables, biogas electricity has mostly higher impacts, with a few exceptions. For example, biogas has a lower AP than geothermal power across all the AD-CHP plants considered. Furthermore, Plant 5 has lower GWP and Plant 2 lower POCP than any other renewable option. Biogas is also better than solar PV in terms of ADP elements, HTP, FAETP, MAETP, ODP, and

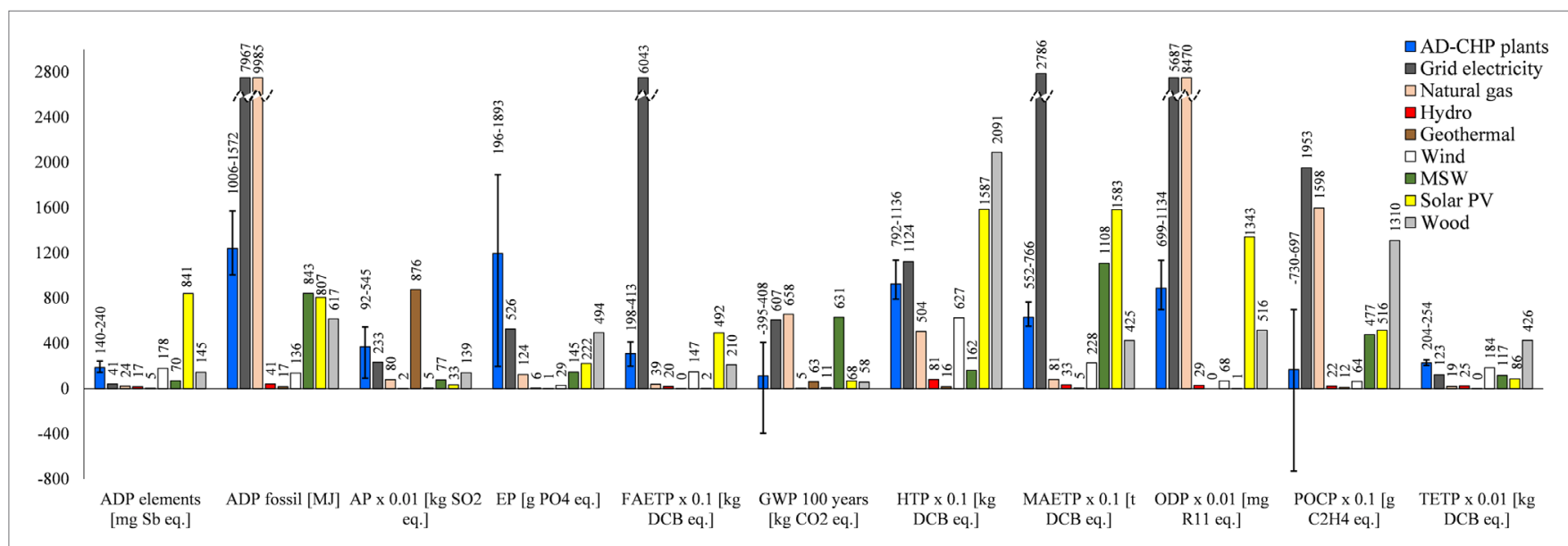

FIGURE 6 | Comparison of biogas electricity with the alternatives. All impacts expressed per megawatt hour of electricity. For the AD-CHP plants, the average results are shown, with the error bars representing the impacts ranges for different plants. For impacts nomenclature, see Figure $\mathbf{5}$. MSW, municipal solid waste; wood, wood chips in a CHP plant.

\begin{tabular}{|c|c|c|c|c|c|c|c|c|c|c|c|c|c|}
\hline & Plant 1 & Plant 2 & Plant 3 & Plant 4 & Plant 5 & Grid electricity & Natural gas & Hydro & Geothermal & Wind & MSW & Wood & Solar PV \\
\hline ADP elements & $2 \%$ & $3 \%$ & $2 \%$ & $3 \%$ & $2 \%$ & $0.5 \%$ & $0.3 \%$ & $0.2 \%$ & $0.1 \%$ & $2 \%$ & $1 \%$ & $2 \%$ & $100 \%$ \\
\hline ADP fossil & $10 \%$ & $13 \%$ & $13 \%$ & $16 \%$ & $10 \%$ & $80 \%$ & $100 \%$ & $0.4 \%$ & $0.2 \%$ & $1 \%$ & $8 \%$ & $6 \%$ & $8 \%$ \\
\hline AP & $29 \%$ & $53 \%$ & $56 \%$ & $62 \%$ & $11 \%$ & $27 \%$ & $9 \%$ & $0.2 \%$ & $100 \%$ & $1 \%$ & $9 \%$ & $16 \%$ & $4 \%$ \\
\hline EP & $41 \%$ & $81 \%$ & $84 \%$ & $100 \%$ & $10 \%$ & $28 \%$ & $7 \%$ & $0.3 \%$ & $0.1 \%$ & $2 \%$ & $8 \%$ & $26 \%$ & $12 \%$ \\
\hline FAETP & $4 \%$ & $6 \%$ & $6 \%$ & $7 \%$ & $3 \%$ & $100 \%$ & $1 \%$ & $0.3 \%$ & $0 \%$ & $2 \%$ & $0 \%$ & $3 \%$ & $8 \%$ \\
\hline GWP 100 years & $34 \%$ & $6 \%$ & $62 \%$ & $44 \%$ & $-60 \%$ & $92 \%$ & $100 \%$ & $1 \%$ & $10 \%$ & $2 \%$ & $96 \%$ & $9 \%$ & $10 \%$ \\
\hline HTP & $38 \%$ & $47 \%$ & $44 \%$ & $54 \%$ & $38 \%$ & $54 \%$ & $24 \%$ & $4 \%$ & $1 \%$ & $30 \%$ & $8 \%$ & $100 \%$ & $76 \%$ \\
\hline MAETP & $20 \%$ & $23 \%$ & $21 \%$ & $27 \%$ & $22 \%$ & $100 \%$ & $3 \%$ & $1 \%$ & $0.2 \%$ & $8 \%$ & $40 \%$ & $15 \%$ & $57 \%$ \\
\hline ODP & $9 \%$ & $11 \%$ & $11 \%$ & $13 \%$ & $8 \%$ & $67 \%$ & $100 \%$ & $0.3 \%$ & $0 \%$ & $1 \%$ & $0 \%$ & $6 \%$ & $16 \%$ \\
\hline РOCP & $28 \%$ & $-8 \%$ & $36 \%$ & $24 \%$ & $-37 \%$ & $100 \%$ & $82 \%$ & $1 \%$ & $1 \%$ & $3 \%$ & $24 \%$ & $67 \%$ & $26 \%$ \\
\hline TETP & $48 \%$ & $56 \%$ & $53 \%$ & $60 \%$ & $51 \%$ & $29 \%$ & $5 \%$ & $6 \%$ & $0 \%$ & $43 \%$ & $27 \%$ & $100 \%$ & $20 \%$ \\
\hline
\end{tabular}

FIGURE 7 | Heat map of environmental impacts from biogas electricity and the alternatives considered in this study. The worst option is set at $100 \%$ and the others are expressed as a percentage of impact relative to the worst option. Waste, municipal solid waste; MSW, municipal solid waste; wood, wood chips in a CHP plant; solar PV, solar photovoltaics. For impacts nomenclature, see Figure 5. 
POCP. It also has a lower MAETP than electricity from municipal solid waste and it outperforms wood for HTP, POCP, and TETP.

With a specific reference to GWP, the main driver for biogas production, Plant 5 is the best option overall, sequestering $395 \mathrm{~kg}$ $\mathrm{CO}_{2}$ eq./MWh. All other plants generate higher GHG emissions than any of the renewable options considered here. The only other impact for which biogas electricity is a better option than any other is POCP, but again only for Plant 5; however, this plant has the highest TETP than any other alternative.

These results are summarized in Figure 7, which shows the percentage difference between the worst option and the rest of the alternatives for each impact. Overall, assuming equal importance of all the impacts, hydropower could be considered the best option and grid electricity the worst, with biogas being on average a middle-ranking option.

\section{Comparison with Other Studies}

As discussed in the Section "Introduction," comparison of the results from different studies is not easy for the reasons outlined there. The only studies for which comparison is possible are those by Blengini et al. (2011), Dressler et al. (2012), Meyer-Aurich et al. (2012), Bacenetti et al. (2013), Whiting and Azapagic (2014), and Ingrao et al. (2015); for a summary of these studies, see Table 1.

As can be inferred from Figure 8, the results from the current study compare favorably in terms of AP, EP, GWP, and POCP, given the different assumptions, system credits, and geographical locations across the studies. However, the average GWP estimated in this work appears to be lower than in the other studies, mainly because of Plant 5 which has a negative value for this impact. Nevertheless, the impact for the AD-CHP system using pig slurry reported by Bacenetti et al. (2013) compares well with Plant 5 which uses cow slurry ( -368 and $-395 \mathrm{~kg} \mathrm{CO}_{2}$ eq./MWh, respectively). The GWP in Blengini et al. (2011) is consistent with that estimated for Plant 4 , while the values found by Dressler et al. (2012), Meyer-Aurich et al. (2012), Bacenetti et al. (2013), and Ingrao et al. (2015) agree well with the results for Plants 1 and 3. It should be noted that, unlike other studies, Meyer-Aurich et al. (2012) have considered land-use change (associated with maize cultivation), finding that it increases GWP by $20 \%$; however, differences in other assumptions cancel out this effect and, consequently, the results still agree with those in the current study.

The comparison of the other impacts is only possible with the study by Whiting and Azapagic (2014), since the other authors did not consider them. As can be seen in Figure 8, the results agree for HTP but differ for ADP, FAETP, MAETP, ODP, and TETP. The reason for these differences could be due to the different updates of the CML method and Gabi software, as well as the different assumptions, credits for fertilizers, and geographical locations. On the other hand, both studies are in agreement that the contribution of the $\mathrm{AD}$ and $\mathrm{CHP}$ plants construction is significant for $\mathrm{ADP}$ elements and the toxicity-related impacts.

\section{Sensitivity Analysis}

Because of their significant contribution to the impacts, the following parameters are considered in the sensitivity analysis:

(i) maize yield;

(ii) heat utilization;

(iii) recycling of $\mathrm{AD}$ and $\mathrm{CHP}$ construction materials; and

(iv) covered storage of digestate in Plant 4.

The results are discussed in the following sections.

\section{Maize Yield}

To explore the effect of this parameter on the impacts, the maize yield was varied by $\pm 15 \%$ against the baseline shown in Table S2 in Supplementary Material. The results in Figure 9 suggest that the overall effect of maize yield on the environmental impacts is

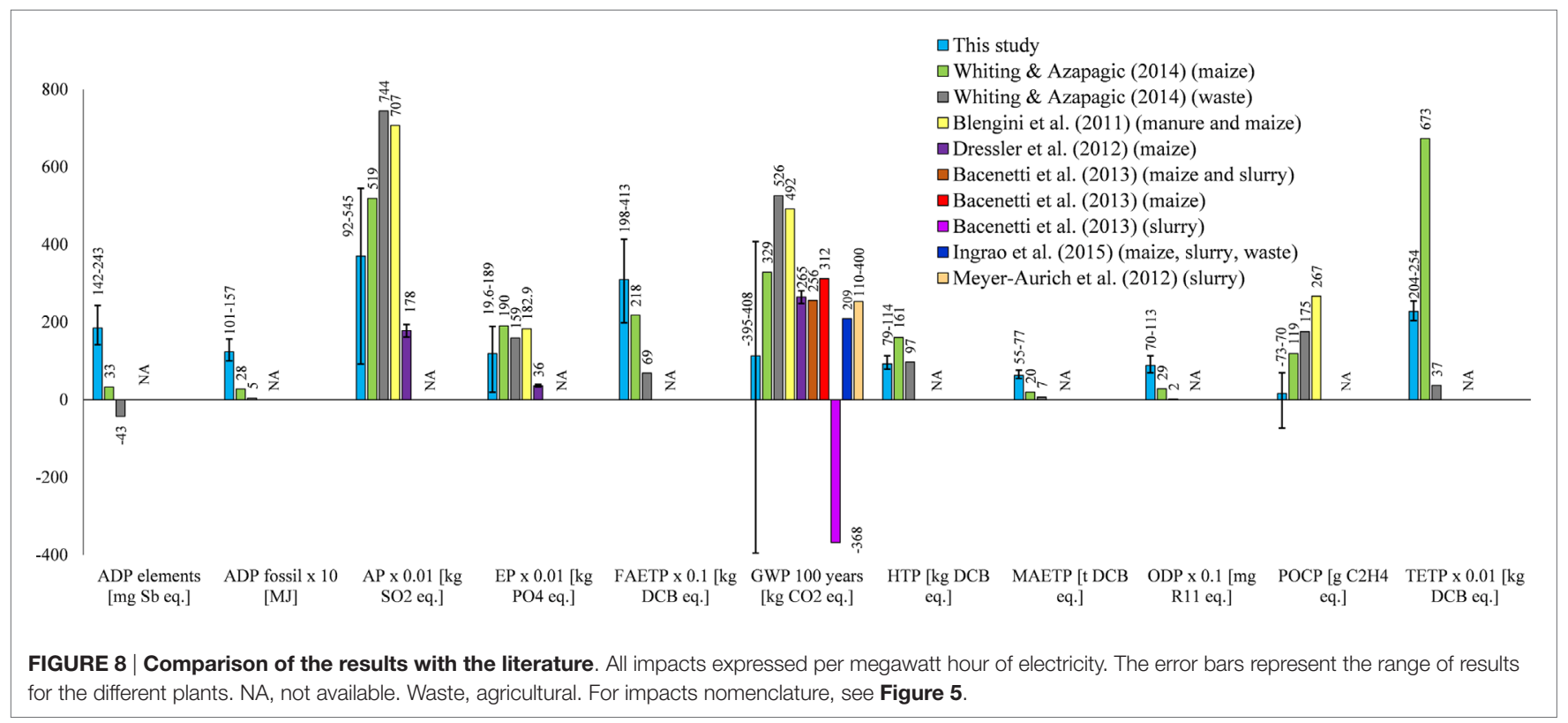




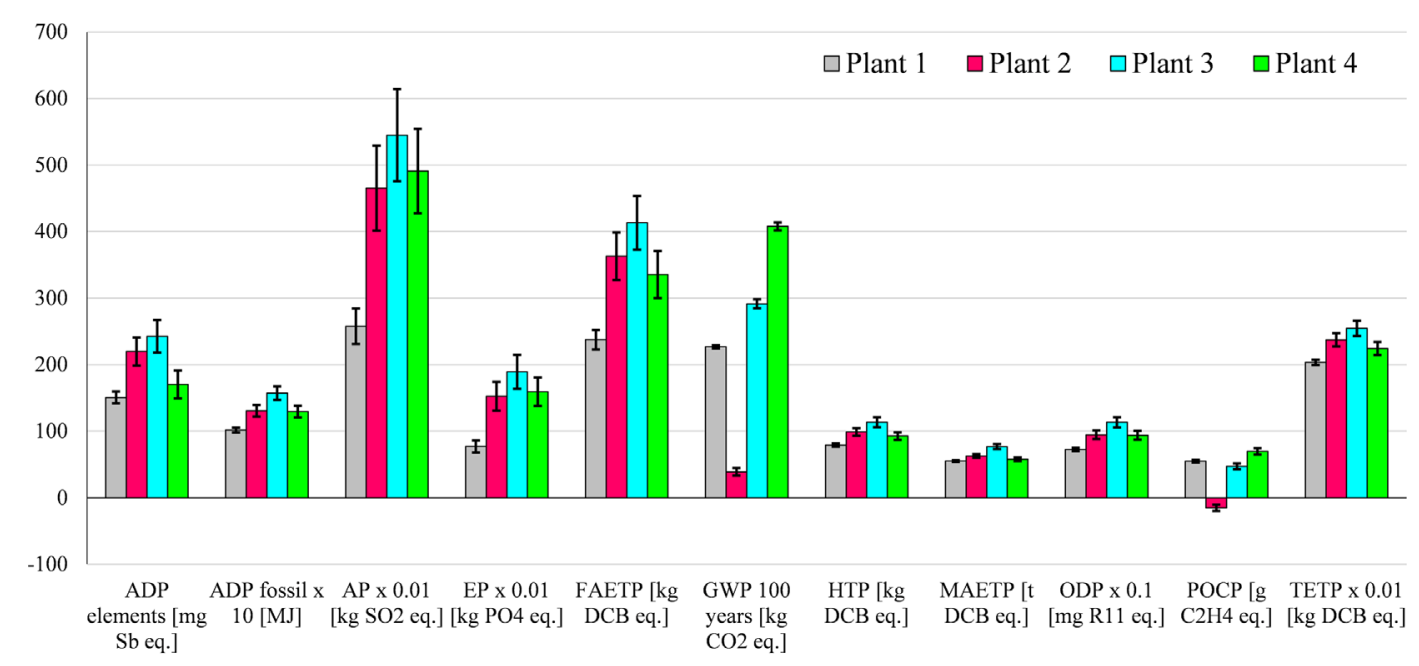

FIGURE 9 | Sensitivity analysis assuming different maize yields for biogas produced in Plants 1-4. All impacts expressed per megawatt hour of electricity. The height of the columns corresponds to the yield indicated in Table S2 in Supplementary Material. The error bars refer to the yield variation of $\pm 15 \%$. For impacts nomenclature, see Figure 5.

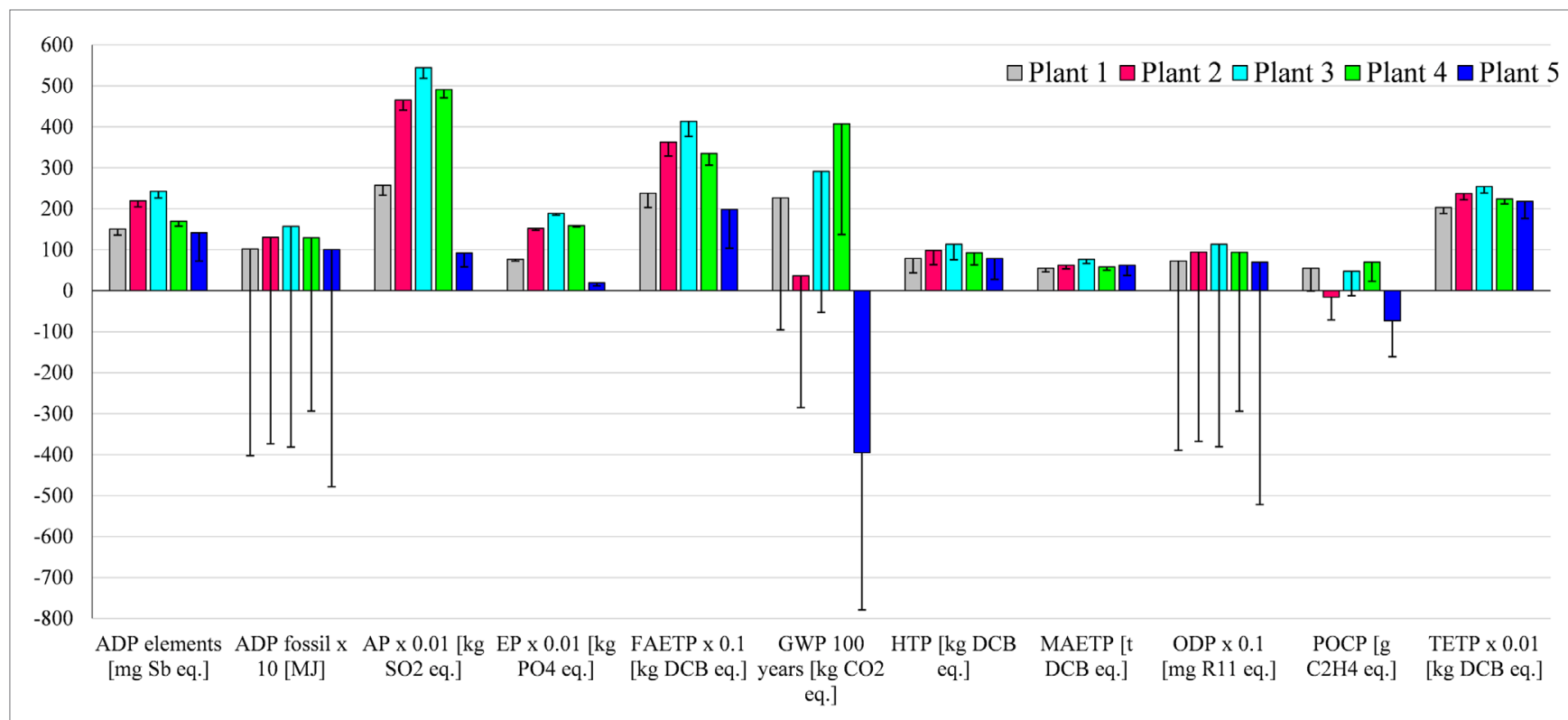

FIGURE 10 | Sensitivity analysis assuming the net heat produced is used and substitutes a gas boiler. All impacts expressed per megawatt hour of electricity. Capacity of boiler: $>100 \mathrm{~kW}$ for Plants $1-4$ and $<100 \mathrm{~kW}$ for Plant 5 . For impacts nomenclature, see Figure 5.

small for most impacts, except for AP and EP which change by up to $14 \%$. This is to be expected given the high contribution of maize cultivation to these categories.

The ADP elements and FAETP results are also affected for Plant 4 , varying by up to $12 \%$, because of the change in the resource requirements for the agricultural machinery and the related toxicity of the construction materials. Despite these changes, the variation in the maize yield considered here does not affect the comparison of biogas with the alternative electricity sources discussed in Section "Comparison with Alternative Electricity Sources."

\section{Heat Utilization}

This part of the sensitivity analysis considers a scenario in which the net heat produced by the CHP plants is used instead of being wasted. This is motivated by the introduction of subsidies for heat (see Introduction), which aim to stimulate its utilization. It was assumed that the heat generated by the CHP substitutes a gas boiler for which the AD-CHP systems were credited. The LCA data for the boiler were sourced from Ecoinvent (2010).

As indicated in Figure 10, if the heat were utilized all of the impacts would be reduced, some of them significantly, across the 
different plants: ADP fossil would be lower by four to six times, GWP up to nine times, ODP by five to eight times, and POCP two to four times. This means that biogas electricity from all five plants would have lower impacts for these categories than any other renewable option considered here. However, there would be no change in ranking with respect to grid electricity because ADP elements, AP, EP, and TETP remain higher for biogas electricity.

\section{Recycling of Construction Materials}

As mentioned earlier, it was assumed that all the construction materials apart from plastics are landfilled after decommissioning of the plants. Since the construction of the plants has a significant contribution for some impacts, particularly for Plants 1 and 5 (Figures 5A,E), the sensitivity analysis considers if and how they would change if concrete, steel, iron, and platinum (in the CHP catalytic converter) were recycled. For these purposes, the recycling rates for the former three materials were assumed equal to current recycling rates in Italy: $60 \%$ for concrete (UNI, 2005) and $74 \%$ for steel and iron (Fondazione per lo sviluppo sostenibile, 2012). As there are no data for platinum recycling, a recovery rate of $90 \%$ was assumed. Plastic materials were not considered for recycling as their quantity is small.

The results are presented in Figure $\mathbf{1 1}$ for the impacts that are affected by the recycling. The greatest reduction would be achieved for ADP elements (up to 39\%) and POCP (up to $13.5 \%$ ), followed by AP and FAETP ( 8\%); MAETP would also go down $(\sim 5 \%)$. The effect on the other impacts is small $(<2 \%)$.

\section{Covered Storage of Digestate}

As discussed in Section "Results," biogas electricity from Plant 4, which uses maize silage as the AD feedstock, has higher GWP and POCP than any other plant. Given that much of that is due to methane emissions from the open storage of digestate
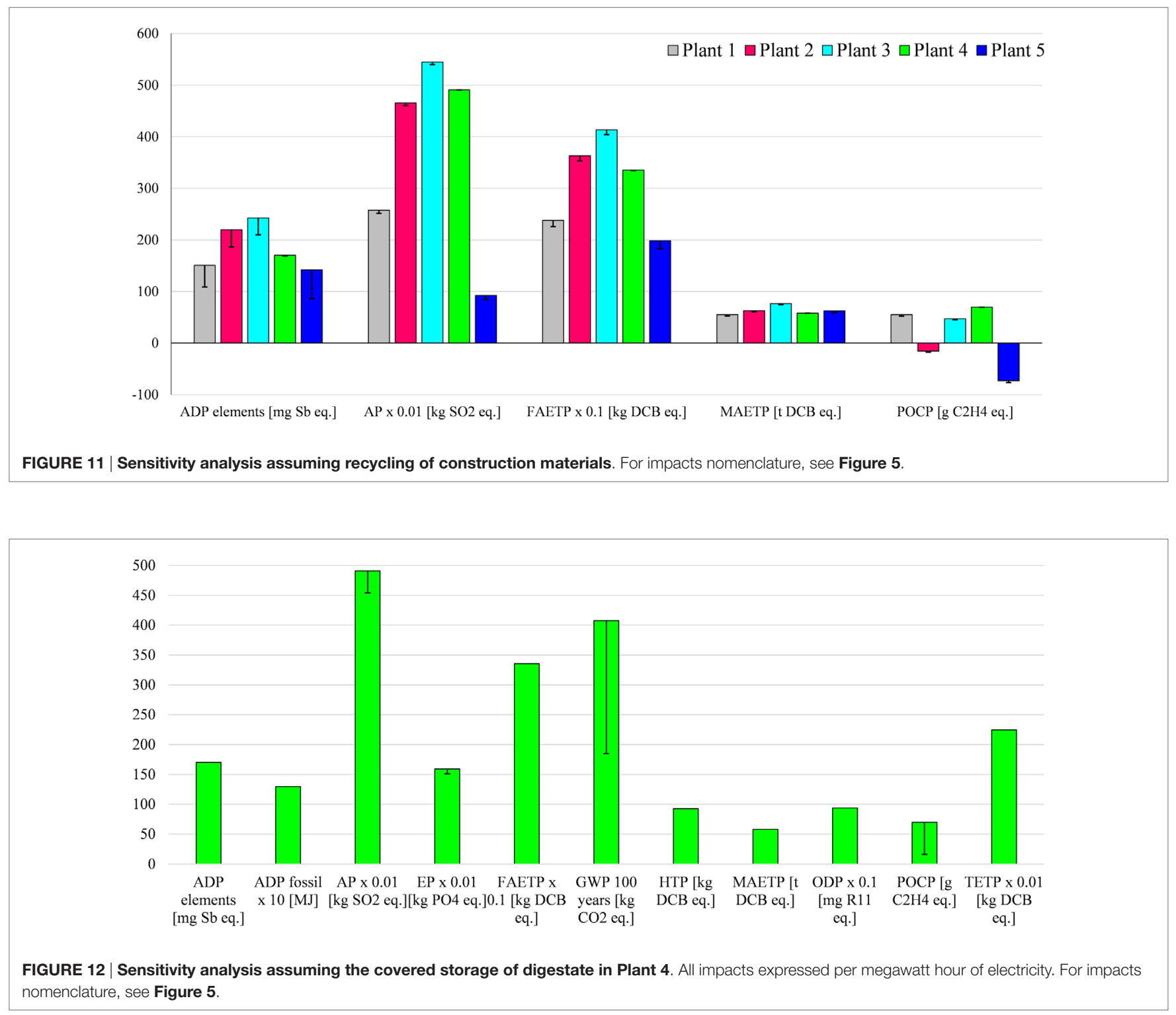
(Figure 5D), it is important to consider by how much the impacts would change if the digestate were stored in covered tanks, as in Plant 2.

The results in Figure 12 suggest that both impacts would decrease significantly: GWP by two times and POCP threefold. In that case, Plant 4 would have lower impacts than Plant 1 and 3 but still higher than Plant 2. The AP and EP results would also be reduced, by 7 and 5\%, respectively, because of the avoided ammonia emissions. This would make Plant 4 a better option than Plant 2 for these two impacts.

With respect to grid electricity, Plant 4 would have half the GWP. It would also be a better option for POCP with respect to solar PV and waste power plants.

\section{CONCLUSION}

The aim of this study was to evaluate the life cycle environmental impacts associated with generation of electricity from biogas produced by $\mathrm{AD}$ of agricultural products and waste. Five real $\mathrm{AD}-\mathrm{CHP}$ plants situated in Italy were considered and compared to electricity from the national grid, natural gas, and different renewable technologies.

The results suggest that the main contributors to the impacts from biogas electricity are the production of the maize silage and the operation of the anaerobic digester, including open storage of digestate. Therefore, the system using animal slurry (Plant 5) is the best option among the five plants considered, except for marine and terrestrial ecotoxicity potentials for which the best system is the one utilizing slurry, agricultural waste, and a small amount of maize silage (Plant 1). The plant fed with maize ear silage (Plant 3 ) is the worst option because of the high impacts of the feedstock, which are almost double that of maize silage.

In reference to the size of AD-CHP plants, larger capacity does not appear to have a positive effect on environmental impacts despite the higher efficiencies typically associated with economies of scale. This is due to the larger plants requiring a high organic load to make them viable, which can only be achieved with cereal feedstocks as they have much higher biogas yield than slurry or agricultural waste. For example, a $1 \mathrm{MW} \mathrm{CHP}$ plant requires around 50 ton of maize silage per day but 400-800 ton of slurry. As this amount of slurry cannot be supplied by a single farm, it would have to be collected from different farms and transported to the plant which would not be economically and environmentally viable. Furthermore, the digester would be impractically large (20,000-40,000 $\mathrm{m}^{3}$ assuming a hydraulic retention time of 50 days) and thus expensive. Therefore, as the results of this work suggest, it is better to have smaller plants using slurry and waste rather than bigger installations: the latter may be more efficient but require cereal silage, which in turn leads to higher environmental impacts. On the other hand, smaller plants require more resources for construction per unit of electricity generated, so there are some trade-offs.

The results also suggest that utilizing the heat generated by the CHP plant would reduce all the impacts, some of them significantly (specifically depletion of fossil fuels and the ozone layer, global warming, and summer smog), making biogas electricity a better option for these categories than any other renewable alternatives considered here. Recycling the $\mathrm{AD}$ and $\mathrm{CHP}$ construction materials would reduce the depletion of elements, acidification, freshwater, and marine toxicity as well as summer smog. The latter would also improve in addition to global warming if digestate was stored in covered tanks.

Biogas electricity is environmentally more sustainable than electricity from the grid for seven out of 11 impacts considered. This is due to the high contribution of fossil fuels in the Italian electricity mix. The remaining four impacts, for which grid electricity is a better option, are depletion of elements, acidification, eutrophication, and terrestrial ecotoxicity. Thus, biogas electricity reduces GHG emissions compared to the grid, as intended by government and the European Commission, but aggravates some other impacts.

However, in comparison with natural gas, seven out of 11 impacts are higher for electricity from biogas. It also has mostly higher impacts than the renewables, except for solar PV for which six out of 11 impacts are higher than biogas. Furthermore, biogas is a better option than geothermal power for acidification across all the feedstocks considered. If only slurry is used (Plant 5), it also has lower global warming and summer smog potentials than geothermal. Moreover, marine ecotoxicity is greater for electricity from municipal solid waste than that from biogas.

Focusing on global warming potential which drives biogas production, using slurry as a feedstock (Plant 5) is the best option across all the electricity options considered here, sequestering $395 \mathrm{~kg} \mathrm{CO}$ eq./MWh. All the other biogas systems generate higher greenhouse emissions than any of the renewable options considered here. The only other impact for which biogas electricity is a better option than any other is summer smog, but only for the slurry feedstock; however, it also has higher terrestrial ecotoxicity than any other electricity alternative.

In summary, biogas electricity can help reduce GHG emissions relative to fossil-intensive grid electricity such as that of Italy; however, some other impacts are increased. On the other hand, if mitigation of climate change is the main aim, then other renewables have a greater potential to reduce GHG emissions. If, in addition to this, other impacts are considered, then hydro, wind, and geothermal power are better alternatives to biogas. However, if the subsidies for heat utilization are successful, the environmental sustainability of biogas electricity would improve significantly, particularly for global warming, summer smog, and depletion of the ozone layer and abiotic resources. Further policy changes should include a ban on open digestate storage to prevent methane emissions and regulation on digestate spreading on land to minimize emissions of ammonia and related environmental impacts.

Finally, it should be noted that the results obtained in this study correspond to mesophilic digestion at $40^{\circ} \mathrm{C}$ and may differ from the results for other operating conditions. Furthermore, the analysis did not consider other environmental aspects, such as habitat destruction and biodiversity loss, as they are outside the scope of LCA. These and other impacts could be evaluated in future research alongside economic costs and social impacts as part of a broader sustainability assessment. 


\section{AUTHOR CONTRIBUTIONS}

$\mathrm{AA}$ and MF conceived and supervised the work; JB collected the data; AF carried out the LCA study; AA, AF, and JB wrote the paper.

\section{ACKNOWLEDGMENTS}

This work was funded by the UK Engineering and Physical Sciences Research Council (EPSRC), grant no. EP/K011820/1. This funding is gratefully acknowledged. The authors are also

\section{REFERENCES}

Amon, B., Kryvoruchko, V., Amon, T., and Zechmeister-Boltenstern, S. (2006). Methane, nitrous oxide and ammonia emissions during storage and after application of dairy cattle slurry and influence of slurry treatment. Agric. Ecosyst. Environ. 112, 153-162. doi:10.1016/j.agee.2005.08.030

Audsley, E. (1997). Harmonization of Environmental Life Cycle Assessment for Agriculture. European Commission DG VI Agriculture. Silsoe: Silsoe Research Institute.

Bacenetti, J., Duca, D., Fusi, A., Negri, M., and Fiala, M. (2015). Mitigation strategies in the agro-food sector: the anaerobic digestion of tomato puree by-products. An Italian case study. Sci. Total Environ. 526, 88-97. doi:10.1016/j. scitotenv.2015.04.069

Bacenetti, J., and Fiala, M. (2015). Carbon footprint of electricity from anaerobic digestion plants in Italy. Environ. Eng. Manag. J. 14, 1495-1502.

Bacenetti, J., Negri, M., Fiala, M., and Gonzalez Garcia, S. (2013). Anaerobic digestion of different feedstock: impact on energetic and environmental balances of biogas process. Sci. Total Environ. 46, 541-551. doi:10.1016/j. scitotenv.2013.06.058

Blengini, G. A., Brizio, E., Cibrario, M., and Genon, G. (2011). LCA of bioenergy chains in Piedmont (Italy): a case study to support public decision makers towards sustainability. Resour. Conserv. Recycl. 57, 36-47. doi:10.1016/j. resconrec.2011.10.003

Bodria, L., Pellizzi, G., and Piccarolo, P. (2006). Il trattore e le macchine operatrici. Bologna: Ed. Edagricole.

Boschiero, M., Kelderer, M., and Zerbe, S. (2014). "Handling agricultural residues in LCAs - a case study on woodchips from apple orchards in South Tyrol," in Proceedings Convegno della Rete Italiana LCA, Florence.

Brentrup, F., Küsters, J., Lammel, J., and Kuhlmann, H. (2000). Methods to estimate on-field nitrogen emissions from crop production as an input to LCA studies in the agricultural sector. Int. J. Life Cycle Assess. 5, 349-357. doi:10.1007/ BF02978670

Brizzo, F. (2015). Biogas: l'Italia è terzo produttore al mondo dopo Germania e Cina. La Stampa. Available at: www.lastampa.it/2015/02/01/scienza/ambiente/ focus/biogas-litalia-terzo-produttore-al-mondo-dopo-germania-e-cina-OSjLZIsghgUmMloNF7mxIN/pagina.html

Casati, D. (2011). Le superfici possono ricominciare a salire. Terra e Vita 35, 40-46.

Cellura, M., Ardente, F., and Longo, S. (2012). From the LCA of food products to the environmental assessment of protected crops districts: a case-study in the south of Italy. J. Environ. Manag. 93, 194-208. doi:10.1016/j.jenvman.2011.08.019

Chen, S., Chen, B., and Song, D. (2012). Life-cycle energy production and emissions mitigation by comprehensive biogas-digestate utilization. Bioresour. Technol. 114, 357-64. doi:10.1016/j.biortech.2012.03.084

Coulson, J. M., Richardson, J. F., and Sinnott, R. K. (1993). Chemical Engineering. Oxford: Butterworth-Heinemann.

Curran, A. M. (2012). Life Cycle Assessment Handbook: A Guide for Environmentally Sustainable Products. New Jersey: John Wiley \& Sons and Scrivener Publishing.

De Vries, J. W., Corré, W. J., and Dooren, H. J. (2010). Environmental Assessment of Untreated Manure Use, Manure Digestion and Co-Digestion with Silage Maize. Wageningen: Wageningen UR Livestock Research.

De Vries, J. W., Vinken, T. M. W. J., Hamelin, L., and De Boer, I. J. M. (2012). Comparing environmental consequences of anaerobic mono- and co-digestion of pig manure to produce bio-energy e a life cycle perspective. Bioresour. Technol. 125, 239-248. doi:10.1016/j.biortech.2012.08.124 grateful to the editor and the reviewers for their comments that helped to improve the paper. We would also like to thank Dr. Laurence Stamford and Ellen Gleeson at the University of Manchester for proofreading the manuscript and Dr. Martyn Jones, also at Manchester, for his assistance with the figures.

\section{SUPPLEMENTARY MATERIAL}

The Supplementary Material for this article can be found online at http://journal.frontiersin.org/article/10.3389/fbioe.2016.00026

Dressler, D., Loewen, A., and Nelles, M. (2012). Life cycle assessment of the supply and use of bioenergy: impact of regional factors on biogas production. Int. J. Life Cycle Assess. 17, 1104-1115. doi:10.1007/s11367-012-0424-9

Ebner, J. H., Rodrigo, A., Labatut, R. A., Rankin, M. J., Pronto, J. L., Gooch, C. A., et al. (2015). Lifecycle greenhouse gas analysis of an anaerobic codigestion facility. Environ. Sci. Technol. 49, 199-208. doi:10.1021/acs.est.5b01331

EC. (2009). Directive 2009/28/EC, Promotion of the Use of Energy from Renewable Sources. Luxembourg: Office for Official Publications of the European Communities.

Ecoinvent. (2010). Ecoinvent Database v2.2. Zurich; Lausanne: Ecoinvent.

Edelmann, W., Schleiss, K., Engeli, H., and Baier, U. (2011). Ökobilanz der stromgewinnung aus landwirtschaftlichem Biogas. Bundesamt für Energie. Available at: http://www.halfin.ch/Biogas/Dokumente/oekobilanz\%20landwirtschaft.pdf

EMEP/EEA. (2013). Agriculture Other (Use of Pesticides and Limestone). Air Pollutant Emission Inventory Guidebook 2013. Technical Report, No. 12/2013. Copenhagen: European Environment Agency.

EurObserv'ER. (2014). EurObserv'ER - Etat des énergies renouvelables en Europe Observ'ER. Paris. Available at: http://www.energies-renouvelables.org/ observ-er/stat_baro/barobilan/barobilan14_FR.pdf

Falcone, G., Strano, A., Stillitano, T., De Luca, A., Iofrida, N., and Gulisano, G. (2015). Integrated sustainability appraisal of wine-growing management systems through LCA and LCC methodologies. Chem. Eng. Trans. 44, 223-228. doi:10.3303/CET1544038

Fantin, V., Rondini, I., Righi, S., Pasteris, A., Coatti, F., Passerini, F., et al. (2015). "Environmental assessment of wheat and maize production in an Italian farmers cooperative," in Proceedings International Conference LCA for Feeding the Planet and Energy for Life, Stresa.

Fiala, M. (2012). Energia da biomasse. Santarcangelo di Romagna: Maggioli Editore.

Fondazione per lo sviluppo sostenibile. (2012). Approfondimenti settoriali dedicati alle singole filiere del riciclo e recupero. Available at: http://www. fondazionesvilupposostenibile.org/

Fuchsz, M., and Kohlheb, N. (2015). Comparison of the environmental effects of manure- and crop-based agricultural biogas plants using life cycle analysis. J. Clean. Prod. 86, 60-66. doi:10.1016/j.jclepro.2014.08.058

Goedkoop, M., and Spriensma, R. (2001). The Eco-Indicator 99: A Damage Oriented Method for Life Cycle Assessment. Methodology Report, 3rd Edn. Amersfoort: Pré Consultants.

Goedkoop, M. J., Heijungs, R., Huijbregts, M., De Schryver, A., Struijs, J., and Van Zelm, R. (2009). ReCiPe 2008, A Life Cycle Impact Assessment Method Which Comprises Harmonised Category Indicators at the Midpoint and the Endpoint Level, 1st ed. Report I: Characterisation. Available at: www.lcia-recipe.net

Guinée, J. B., Gorrée, M., Heijungs, R., Huppes, G., Kleijn, R., Koning, A., et al. (2002). Handbook on Life Cycle Assessment. Operational Guide to the ISO Standards. I: LCA in Perspective. IIA: Guide. IIB: Operational Annex. III: Scientific Background. Dordrecht: Kluwer Academic Publishers, 692.

IEA (International Energy Agency). (2011). OECD - Electricity and Heat Generation. Electricity Information Statistics (Database). Available at: http:// www.oecd-ilibrary.org/energy/

Ingrao, C., Rana, R., Tricase, C., and Lombardi, M. (2015). Application of carbon footprint to an agro-biogas supply chain in Southern Italy. Appl. Energy 149, 75-88. doi:10.1016/j.apenergy.2015.03.111

IPCC. (2006). Agriculture, Forestry and Other Land Use: IPCC Guidelines for National Greenhouse Gas Inventories. Cambridge: Cambridge University Press. 
IPCC. (2007). Climate Change 2007: The Physical Science Basis. Contribution of Working Group I to the Fourth Assessment Report of the Intergovernmental Panel on Climate Change. Cambridge: Cambridge University Press.

ISO. (2006a). ISO 14040. Environmental Management - Life Cycle Assessment Principles and Framework. Geneva: International Organization for Standardization.

ISO. (2006b). ISO 14044. Environmental Management - Life Cycle Assessment - Requirements and Guidelines. Geneva: International Organization for Standardization.

Jin, Y., Chen, T., Chen, X., and Yu, Z. (2015). Life-cycle assessment of energy consumption and environmental impact of an integrated food waste-based biogas plant. Appl. Energy 151, 227-236. doi:10.1016/j.apenergy.2015.04.058

Jury, C., Benetto, E., Koster, D., Schmitt, B., and Welfring, J. (2010). Life cycle assessment of biogas production by monofermentation of energy crops and injection into the natural gas grid. Biomass Bioenergy 34, 54-66. doi:10.1016/j. biombioe.2009.09.011

Lansche, J., and Müller, J. (2012). Life cycle assessment of energy generation of biogas fed combined heat and power plants: environmental impact of different agricultural substrates. Eng. Life Sci. 12, 313-320. doi:10.1002/elsc.201100061

Lijó, L., González-García, S., Bacenetti, J., Fiala, M., Feijoo, G., Lema, J. M., et al. (2014a). Life cycle assessment of electricity production in Italy form anaerobic co-digestion of pig slurry and energy crops. Renew. Energy 68, 625-635. doi:10.1016/j.renene.2014.03.005

Lijó, L., González-García, S., Bacenetti, J., Fiala, M., Feijoo, G., and Moreira, M. T. (2014b). Assuring the sustainable production of biogas from anaerobic mono-digestion. J. Clean. Prod. 72, 23-34. doi:10.1016/j.jclepro.2014.03.022

Lijó, L., González-García, S., Bacenetti, J., Negri, M., Fiala, M., Feijoo, G., et al. (2015). Environmental assessment of farm-scaled anaerobic co-digestion for bioenergy production. Waste Manage. 41, 50-59. doi:10.1016/j.wasman.2015.03.043

Margni, M., Rossier, D., Crettaz, P., and Jolliet, O. (2002). Life cycle impact assessment of pesticides on human health and ecosystems. Agric. Ecosyst. Environ. 93, 379-392. doi:10.1016/S0167-8809(01)00336-X

Meyer-Aurich, A., Schattauer, A., Hellebrand, H. J., Klauss, H., Plöchl, M., and Berga, W. (2012). Impact of uncertainties on greenhouse gas mitigation potential of biogas production from agricultural resources. Renew. Energy 37, 277-284. doi:10.1016/j.renene.2011.06.030

Mezzullo, W., Manus, M., and Hammond, G. (2013). Life cycle assessment of a small-scale anaerobic digestion plant from cattle waste. Appl. Energy 102, 657-664. doi:10.1016/j.apenergy.2012.08.008

Milà i Canals, L. (2007). LCA Methodology and Modelling Considerations for Vegetable Production and Consumption. Working Paper 02/07. Guildford: Centre for Environmental Strategy (CES), University of Surrey.

Ministero dello Sviluppo Economico. (2012). Decreto ministeriale 6 luglio 2012 - Incentivi per energia da fonti rinnovabili elettriche non fotovoltaiche. Roma: Gazzetta Ufficiale della Repubblica Italiana.

Morero, B., Groppelli, E., and Campanella, E. A. (2015). Life cycle assessment of biomethane use in Argentina. Bioresour. Technol. 182, 208-216. doi:10.1016/j. biortech.2015.01.077

Negri, M., Bacenetti, J., Brambilla, M., Manfredini, A., Cantore, C., and Bocchi, S. (2014). Biomethane production from different crop systems of cereals in Northern Italy. Biomass Bioenergy 63, 321-329. doi:10.1016/j. biombioe.2014.01.041

Nemecek, T., and Kägi, T. (2007). Life Cycle Inventories of Agricultural Production Systems. Ecoinvent Report Version 2.0, Vol. 15. Zurich: Swiss Centre for LCI, ART.
NERI. (2010). Emissions from Decentralized CHP Plants. 113. Available at: http:// www2.dmu.dk/pub/FR786.pdf

NNFCC. (2015). Anaerobic Digestion Deployment in the UK. NNFCC. Available at: www.nnfcc.co.uk/tools/nnfcc-report-anaerobic-digestion-deployment-in-the-uk\#sthash.pBZjWiVU.dpuf

Olivier, J., Margni, M., Charles, R., Humbert, S., Payet, J., Rebitzer, G., et al. (2003). IMPACT 2002+: a new life cycle impact assessment methodology. Int. J. Life Cycle Assess. 8, 324-330. doi:10.1007/BF02978505

Pacetti, T., Lombardi, L., and Federici, G. (2015). Water-energy nexus: a case of biogas production from energy crops evaluated by water footprint and life cycle assessment (LCA) methods. J. Clean. Prod. 101, 278-291. doi:10.1016/j. jclepro.2015.03.084

Rodriguez-Verde, I., Regueiro, L., Carballa, M., Hospido, A., and Lema, J. M. (2014). Assessing anaerobic co-digestion of pig manure with agroindustrial wastes: the link between environmental impacts and operational parameters. Sci. Total Environ. 497, 475-483. doi:10.1016/j.scitotenv.2014.07.127

Siduo, Z., Xiaotao, T. B., and Clift, R. (2015). Life cycle analysis of a biogas-centred integrated dairy farm-greenhouse system in British Columbia. Process Saf. Environ. Prot. 93, 18-30. doi:10.1016/j.psep.2014.02.017

Styles, D., Gibbons, J., Williams, A. P., Stichnothe, H., Chadwick, D. R., and Healey, J. R. (2014). Cattle feed or bioenergy? Consequential life cycle assessment of biogas feedstock options on dairy farms. Glob. Change Biol. Bioenergy 7, 1034-1049. doi:10.1111/gcbb.12189

Thinkstep. (2015). Gabi Software-System and Database for Life Cycle Engineering. Stuttgart: Thinkstep.

UNI. (2005). UNI 8520-1: 2005 Aggregati per calcestruzzo - Istruzioni complementari per l'applicazione della EN 12620 - Parte 1: Designazione e criteri di conformità. Available at: www.uni.com/index.php

Wang, Y., Dong, H., Liu, C., and Xin, H. (2014). Comparison of air emissions from raw liquid pig manure and biogas digester effluent storages. Trans. ASABE 57, 635-645. doi:10.13031/trans.57.10292

Weiland, P. (2010). Biogas production: current state and perspectives. Appl. Microbiol. Biotechnol. 85, 849-860. doi:10.1007/s00253-009-2246-7

Whiting, A., and Azapagic, A. (2014). Life cycle environmental impacts of generating electricity and heat from biogas produced by anaerobic digestion. Energy 70, 181-193. doi:10.1016/j.energy.2014.03.103

Xu, C., Shi, W., Hong, J., Zhang, F., and Chen, W. (2015). Life cycle assessment of food waste-based biogas generation. Renew. Sustain. Energy Rev. 49, 169-177. doi:10.1016/j.rser.2015.04.164

Zhang, L. X., Wang, C. B., and Song, B. (2013). Carbon emission reduction potential of a typical household biogas system in rural China. J. Clean. Prod. 47, 415-421. doi:10.1016/j.jclepro.2012.06.021

Conflict of Interest Statement: The authors declare that the research was conducted in the absence of any commercial or financial relationships that could be construed as a potential conflict of interest.

Copyright () 2016 Fusi, Bacenetti, Fiala and Azapagic. This is an open-access article distributed under the terms of the Creative Commons Attribution License (CC BY). The use, distribution or reproduction in other forums is permitted, provided the original author(s) or licensor are credited and that the original publication in this journal is cited, in accordance with accepted academic practice. No use, distribution or reproduction is permitted which does not comply with these terms. 